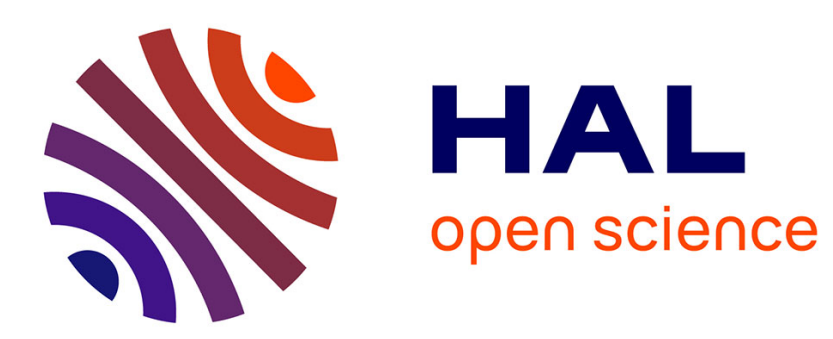

\title{
The evolution of Santa Maria Island in the context of the Azores Triple Junction
}

F. Marques, A. Hildenbrand, A. Costa, A. Sibrant

\section{To cite this version:}

F. Marques, A. Hildenbrand, A. Costa, A. Sibrant. The evolution of Santa Maria Island in the context of the Azores Triple Junction. Bulletin of Volcanology, 2020, 82 (6), 10.1007/s00445-020-01378-4 . hal-03004925

\section{HAL Id: hal-03004925 \\ https://hal.science/hal-03004925}

Submitted on 13 Nov 2020

HAL is a multi-disciplinary open access archive for the deposit and dissemination of scientific research documents, whether they are published or not. The documents may come from teaching and research institutions in France or abroad, or from public or private research centers.
L'archive ouverte pluridisciplinaire HAL, est destinée au dépôt et à la diffusion de documents scientifiques de niveau recherche, publiés ou non, émanant des établissements d'enseignement et de recherche français ou étrangers, des laboratoires publics ou privés. 
This is the peer reviewed accepted version (Author's Accepted Manuscript) of the following article:

Marques, F.O., Hildenbrand, A., Costa, A.C.G. et al. The evolution of Santa Maria Island in the context of the Azores Triple Junction. Bull Volcanol 82, 39 (2020), which has been published in final form at https://doi.org/10.1007/s00445-02001378-4

This article may be used for non-commercial purposes in accordance with SpringerLink Terms and Conditions for Use of Self-Archived Versions 


\title{
The evolution of Santa Maria Island in the context of the
}

\section{Azores Triple Junction}

\author{
F.O. Marques ${ }^{\mathrm{a}^{*}}$, A. Hildenbrand ${ }^{\mathrm{b}}$, A.C.G. $\operatorname{Costa}^{\mathrm{c}}$, A.L.R. Sibrant ${ }^{\mathrm{d}}$ \\ ${ }^{a}$ Universidade de Lisboa, Lisboa, Portugal \\ ${ }^{b}$ GEOPS, Univ. Paris-Sud, CNRS, Université Paris-Saclay, 91405 Orsay, France \\ ${ }^{c}$ IGEM - Institut für geothermisches Ressourcenmanagement, Bingen, Germany \\ ${ }^{d}$ UMR 6538 CNRS, Laboratoire Géosciences Océan LGO, IUEM-UBO, 29280 Plouzané, France \\ *Corresponding author. Tel.: +351 217500000; Fax: +351 217500064 \\ E-mail address: fomarques@fc.ul.pt
}

\section{Abstract}

Santa Maria is the oldest island in the Azores, formerly belonging to the Eurasia plate and currently the only one sitting on the Nubia Plate, thus sharing a geodynamic evolution with the Azores Triple Junction. It is therefore important to evaluate the effects of active tectonics on the evolution of Santa Maria, for example on its vertical movements. We present new stratigraphic, geomorphologic, structural and geochronological data from Santa Maria which shed further light on how a volcanic ocean island evolves in a tectonically active setting. Santa Maria island started with a first shield volcano (Old Volcanic Complex) that emerged ca. 6.0 Ma ago and was active until ca. 5.3 Ma. The short time span between the first and second shield volcanoes (ca. $0.3 \mathrm{Ma}$ ) and the preservation of only the western flank of this first shield volcano indicate an initial flank collapse at ca. $5 \mathrm{Ma}$. The collapse scar was covered by an eastwards dipping sedimentary complex (Intermediate Sedimentary Complex), with a likely tsunami deposit at the base. A second shield volcano (Young Volcanic Complex) rapidly grew on these 
sediments from 4.8 to $3.8 \mathrm{Ma}$, and the island subsided by more than $100 \mathrm{~m}$. At $3.7 \mathrm{Ma}$, a second flank collapse occurred, as inferred from the missing summit and eastern flank. Volcanism then resumed (3.6 to $2.8 \mathrm{Ma}$ ), giving rise to Strombolian cones lying unconformably on the collapse scar, and conformable parasitic cones on the unaffected flank. Submarine lavas occurring at up to $200 \mathrm{~m}$ altitude with a youngest age of 3.0 Ma indicate major uplift of the island since, at most, that time. Here we interpret uplift as the result of rift flank uplift on the southern shoulder of the nearby Terceira Rift in the last ca. $1.5 \mathrm{Ma}$.

Keywords: Santa Maria Island; Azores Triple Junction; large-scale mass wasting; flank collapse; island subsidence and uplift; age fossils

\section{Introduction}

An outstanding problem in volcanic ocean islands close to major plate boundaries is that of evaluating the effect of active tectonics on their evolution. This is particularly so when the island is small and is located in a changing geodynamic setting where the stress field has undergone major changes (Luís ei al., 1994; Mitchell, 2003; Vogt an Jung, 2004; Sibrant et al., 2015a). Additionally, although many volcanic islands around the world record evidence of important vertical displacements, the rates and mechanisms of the associated movements are still debated (e.g. Cas and Wright, 1987; Jones, 1969; Jones and Nelson, 1970; Porebski and Gradzinski, 1990; Ramalho et al., 2010a, b, c, 2013, 2017; Marques et al., 2020). 


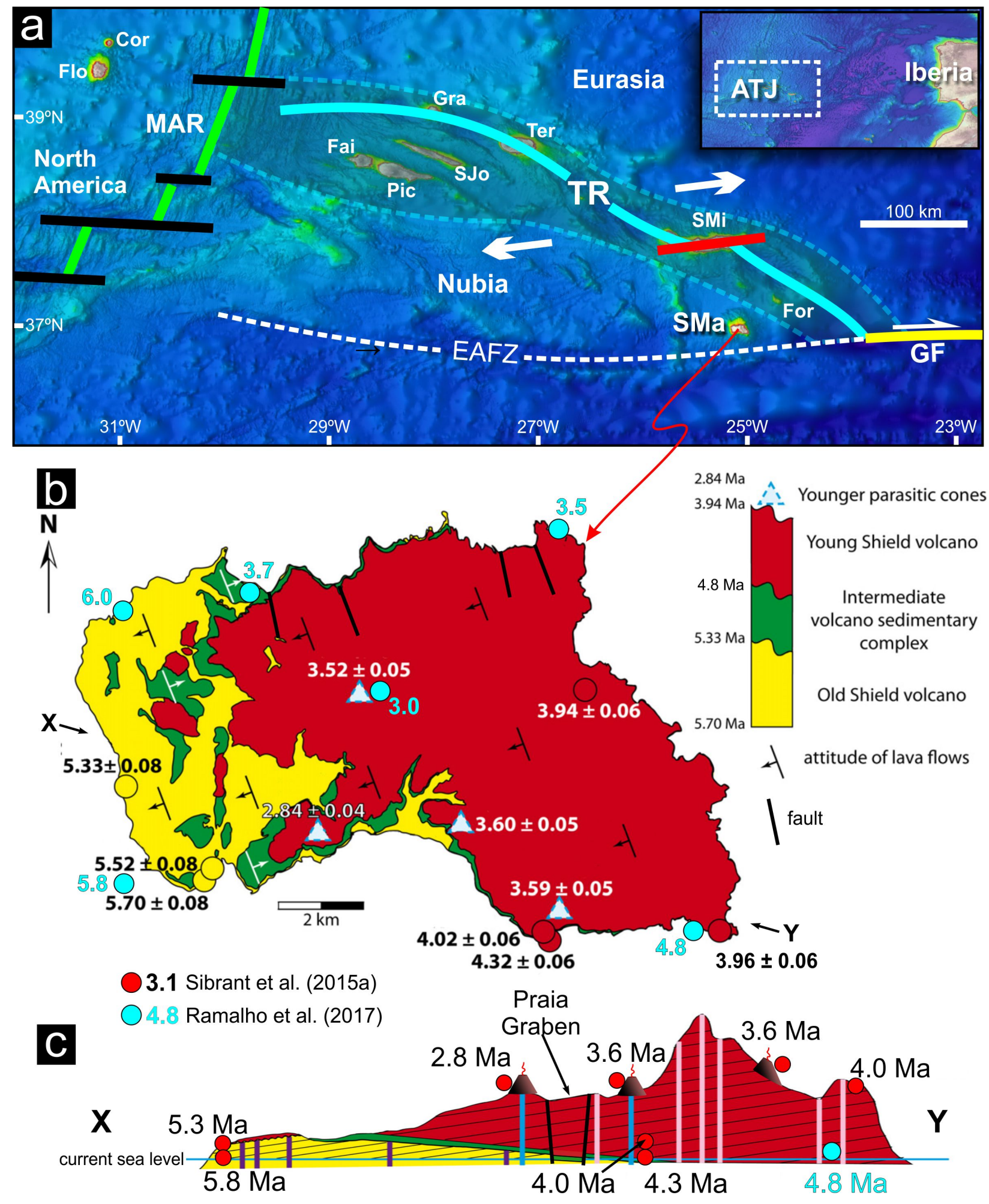

Figure 1. (a) - Tectonic setting of the Azores Triple Junction. MAR and TR (thick green and cyan lines) are the Mid-Atlantic ridge axis and the Terceira Rift, respectively. The light blue shaded area delimited by cyan dashed line marks the diffuse Nubia/Eurasia plate boundary in the Azores (Marques et al., 2013a). Azores islands from west to east: Flo-Flores; Cor - Corvo; Fai-Faial; Pic-Pico; SJo-S. Jorge; Gra-Graciosa; Ter-Terceira; SMi-S. Miguel; SMa - Santa Maria. For-Formigas islets. White arrows on opposite sides of the TR represent the plate velocities (ca. $3.5 \pm 0.5 \mathrm{~mm} / \mathrm{yr}$; Marques et al., 2013a). White half arrow indicates the 
dextral strike-slip motion in the Gloria Fault (GF). The East Azores Fracture Zone (EAFZ) is currently inactive, therefore Santa Maria belongs to the Nubia Plate. Black solid lines transform faults related to the MAR. Red solid line - transform fault related to the TR. Background shaded relief from EMODnet portal (https://www.emodnet-bathymetry.eu/). (b) Simplified geological map of Santa Maria Island adapted from Sibrant et al. (2015a), including previous relevant ages (Sibrant et al., 2015a; Ramalho et al., 2017). (c) - geological profile along $X$-Y in B showing the relationships between the main units, which includes the dip of the lava flows as measured in the field and inferred from the ages. Note the consistency between lava flow dip and younging to the west at sea level in the YVC on the southern coast.

Santa Maria is the easternmost island in the Azores, and lies close to the junction between the East Azores Fracture Zone, the Terceira Rift and the Gloria Fault (Fig. 1). Santa Maria has long been recognized as the oldest island in the Azores archipelago (e.g. Zbyszewski and Ferreira, 1960; Abdel-Monem et al., 1975; Sibrant et al., 2015a; Ramalho et al., 2017). It is also the only island with clear evidence of submarine volcanism well above current sea level (e.g. Serralheiro et al., 1987; Serralheiro and Madeira, 1993; Serralheiro, 2003), and is the island with the most complete marine fossil record (Madeira et al., 2007; Ávila et al., 2018). Santa Maria can be viewed as a reference in the investigation of marine erosion shelves in the Azores and elsewhere (Marques et al., 2016; Ricchi et al., 2018), and the analysis of the shelves in the context of the long-term evolution of Santa Maria is critical to the present study. Constraining the age of marine fossils is very important to our study because they provide information on where the sea was at a given age (palaeoshoreline markers), and so help in the analysis of the vertical movements (mostly subsidence during YVC growth). We thus carried out our study in Santa Maria for three reasons: First, the island has grown in a tectonic setting that has changed over its $>6$ Ma lifetime, thus possibly recording important steps in the evolution of the Azores Triple Junction (ATJ). Second, the evolution of the island is still not well understood, with gaps in our knowledge especially regarding stratigraphy, structure and tectonics, as well as strain and stress evolution. In this regard, geochronological data is used to constrain the age of the different volcanic complexes, the age of the inferred large-scale mass wasting (LSMW), and the age of the 
different fossil deposits. Third, it is a very small island, therefore seemingly not prone to LSMW (Mitchell, 2003; Hildenbrand et al., 2018), which is in apparent contradiction with the LSMW inferred in Santa Maria.

In order to answer the questions about the tectonic evolution of this volcanic island, we needed to: first establish a well-constrained volcanic stratigraphy, from which we could infer the evolution of the island and, in particular, the ages of the abundant fossil deposits In parallel with this, we needed to constrain the geometry of the major shield volcanoes and the position of the main feeding centres, from which we could infer the missing portions of the shield volcano, discuss the origin of the major unconformities in terms of marine/meteoric and LSMW types of erosion, and discuss ages and triggering mechanisms. Second, we needed to identify probable tsunami deposits, and young smaller-scale landslides that shaped the marine shelves to the east, south and west of Santa Maria, as well as to analyse Santa Maria's vertical movements and discuss their rates and mechanisms. Third, we needed to determine the orientation of the stress field from the observed deformation and dykes, and to discuss the relationship between the evolutions of Santa Maria and the ATJ. To accomplish these objectives, we analysed aerial images and digital elevation models for geomorphological and geological interpretations. This was accompanied by fieldwork to identify the major unconformities and volcanic units, and to find and measure faults and dykes. These data were used to unravel the geometry and position of the main volcanoes, and to find the critical palaeodepth markers (palaeoshorelines). Finally, sampling for high-precision K-Ar dating was carried out and used to calibrate the volcanic stratigraphy and to constrain fossil ages and critical palaeodepth markers. The present work builds on that of Marques et al. (2013b) and Sibrant et al. (2015a), by adding new field, geochronological and structural/tectonic data, which together made it possible to accomplish the objectives listed above. 


\section{Geological setting}

Early geological mapping of Santa Maria (Agostinho, 1937; Zbyszewski and Ferreira, 1960) distinguished two main volcanic units separated by a volcano-sedimentary complex. The abundant marine fossils allowed Zbyszewski and Ferreira (1960) to propose minimum and maximum ages for the older (pre-Vindobonian) and younger (post-Vindobonian) volcanic complexes, respectively (Vindobonian - ca. 16 to $7 \mathrm{Ma}$ ). Serralheiro et al. (1987) later introduced three additional units. As a result, the stratigraphy becomes, from the bottom up: (1) two very small and poorly outcropping formations, one submarine (Cabrestantes Formation) and the other sub-aerial (Porto Formation); (2) the sub-aerial Anjos Volcanic Complex; (3) a mixed sub-aerial and submarine volcano-sedimentary complex, the Touril Complex; (4) a submarine volcanic complex, the Facho Complex; (5) the mixed submarine and sub-aerial Pico Alto Complex; and (6) the Feteiras Formation, which is composed of sub-aerial Strombolian cones and widespread pyroclasts.

Based on the recognition of major unconformities and K-Ar dating, Sibrant et al. (2015a) identified three main units: the Older Shield Volcano (ca. 5.7 to 5.3 Ma, which corresponds to the Anjos Complex and includes the Cabrestantes and Porto formations of Serralheiro et al., 1987), the Intermediate volcano-sedimentary Complex (5.3 to 4.3 Ma, far from Vindobonian, which corresponds to the Touril Complex of Serralheiro et al., 1987), and the Younger Shield Volcano (ca. 4.3 to $2.8 \mathrm{Ma}$, which encompasses the Facho and Pico Alto complexes of Serralheiro et al., 1987) with parasitic Strombolian cones on top (which correspond to the Feteiras Formation of Serralheiro et al., 1987). Based on lava flow geometry, as well as the geometry and location of the two shield volcanoes, plus the nature and shape of the major unconformities, Marques et al. (2013b) and Sibrant et al. (2015a) inferred the existence of two large-scale flank collapses. The first occurred between ca. 5.3 and 4.3 Ma, and the second at ca. 3.6 Ma. Ramalho et al. (2017) dated submarine rocks in SE Santa Maria at ca. 4.8 Ma (Fig. 1), 
which constrains the volcanic stratigraphy, since it is the oldest age of the Younger Shield Volcano. The 4.8 Ma age thus narrows the age interval for the first flank collapse, which lies between the youngest age of the Older Shield Volcano and the oldest age of the Younger Shield Volcano.

\section{Methods}

We started with a morphological analysis of the island using a digital elevation model (DEM) with a spatial resolution of $10 \mathrm{~m}$, in order to identify the main morpho-structural units and better define areas of interest for fieldwork. The DEM was produced from a digital topographic map of Santa Maria Island made by the Centro de Informação Geoespacial do Exército (CIGeoE), and the full process is described in Costa et al. (2014). Given that most of the outcrops are on the coast, we went around the island by boat to get a full picture of the main volcanic sequences and their first-order unconformities, faults and dykes. Field work was then carried out over the whole island on road cuts, quarries, and those sea cliffs accessible from the landward side. We systematically measured the attitude of lava flows, faults and dykes, and reconstructed the geometry of major unconformities (mostly landslide scars).

We measured 225 dykes, mostly on the coast, and plotted their dip and strike on graphs. We also used previous geological maps where dykes had been mapped in detail inland. In many dykes we also measured thickness and noted the number of dykes in multiple intrusions. We measured the attitude of 41 faults and striations mostly on the coast, and plotted them on graphs. When visible, we also measured fault striations and noted kinematic indicators for fault movement.

We took advantage of Santa Maria's high coastal cliffs to investigate and sample the base and top of lava flow piles. We collected many more samples than reported here and in Sibrant et al. (2015a). However, due to limited funding in our project only critical samples were dated to 
complement the K-Ar and ${ }^{40} \mathrm{Ar} /{ }^{39} \mathrm{Ar}$ ages acquired on separate phases in Santa Maria (Sibrant et al., 2015a; Ramalho et al., 2017). We focused on the oldest age and setting of the OVC (samples SMA16B, G and K; Fig. 2a for location) to better constrain the oldest stratigraphy and vertical displacements, as well as the age of the submarine YVC close to sedimentary deposits with marine fossils (sample SMA16O; Fig. 2a for location) to better constrain their age and the vertical displacements in Santa Maria. For a detailed description of the K-Ar method used in this study see Appendix 1 in the supplementary material.

\section{Results}

\subsection{Topography/bathymetry}

Morphologically, Santa Maria can be divided into two distinct parts (Fig. 2). The first is the low-lying western half, which is gently sloping to the west. This surface is most likely structural, as it generally follows the westward gentle dip of the OVC and YVC lava flows (Fig. S-1). The flat shelf on which the airport lies, close to the western coast, could be a palaeoshelf, as proposed by Ramalho et al. (2017). (2) The second part is the higher and more rugged eastern half of the island, whose highest peak is at an altitude of ca. $590 \mathrm{~m}$ and comprises a deeply eroded portion of the YVC. The divide between the two parts is rather sharp and arcuate, and concave to the east (Fig. 2).

In detail, there are other curved, concave seaward topographies that shape the coast line (Fig. 2b). These could well correspond to eroded scars of smaller scale landslides. Offshore, there is also a topographic asymmetry, with the marine shelf being much wider in northern Santa Maria than elsewhere around the island. The shelf edge to the north lies between ca. $-120 \mathrm{~m}$ and $-200 \mathrm{~m}$, and extends up to $7 \mathrm{~km}$ offshore (Fig. 2b). In contrast, elsewhere around the island the edge of the marine shelf is at $<-100 \mathrm{~m}$, locally even $<-50 \mathrm{~m}$, and is much narrower $(<1.5 \mathrm{~km})$ (Fig. 2b). Ricchi et al. (2018) analysed in detail the marine shelf, and concluded that the spatial 
sea level fluctuations, vertical displacements, and the intensity of marine erosion.
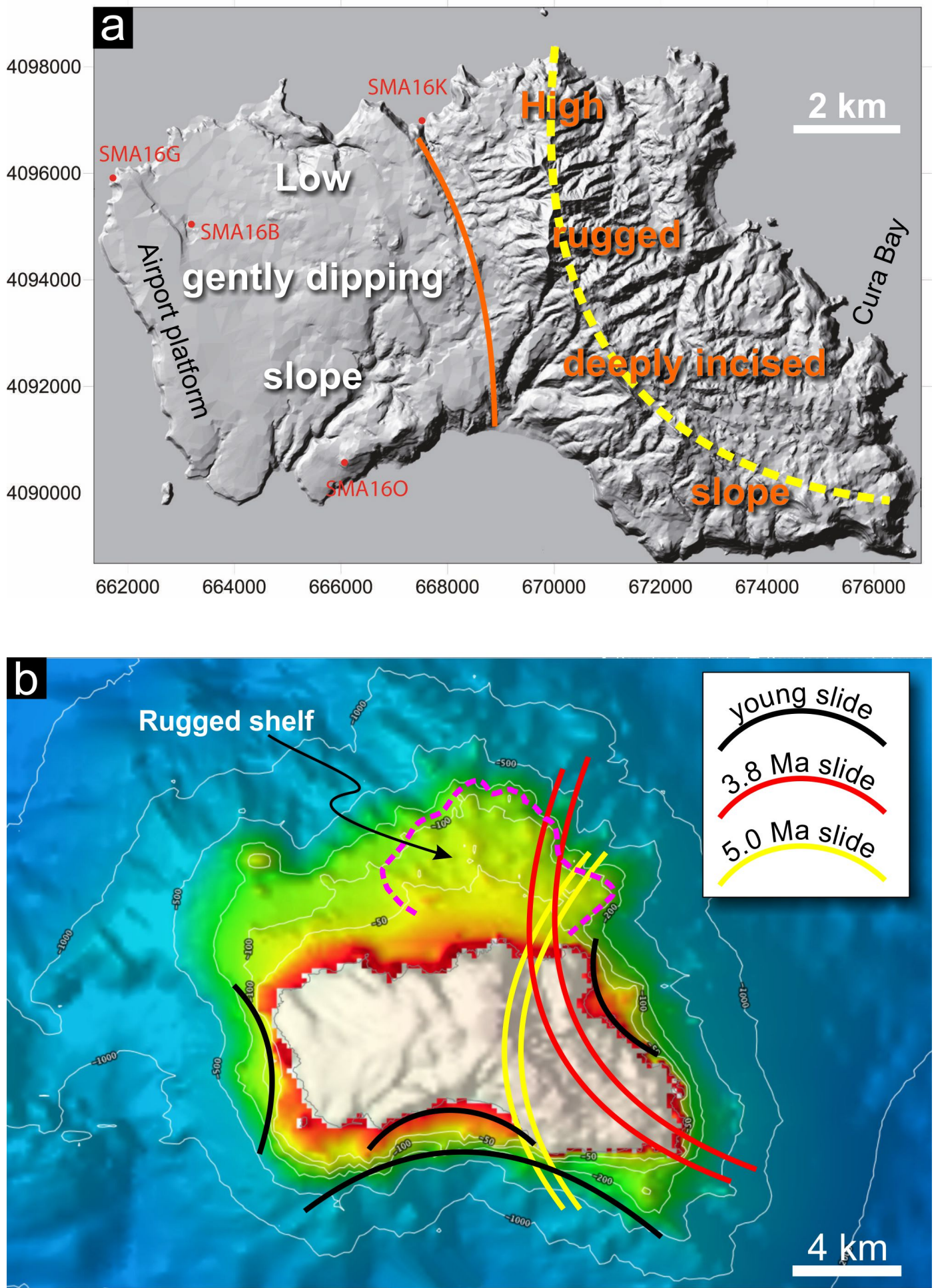

Figure 2. Shaded relief maps to show the main features of the onshore (a) and offshore (b) topography. (a) - the onshore shaded relief shows that the island is morphologically made up of a low, westward gently dipping slope in the western half, and a high (590 m maximal altitude), steep and deeply incised slope in the eastern half. Yellow dashed line marks the position of the divide. (b) - position of here inferred young (black lines, small-scale slides partly destroying the island and younger than $2 \mathrm{Ma}$ ), intermediate (red lines, large-scale slide partly destroying the 
island at ca. 3.8 Ma), and old (yellow lines, large-scale slide partly destroying the island at ca. $5.0 \mathrm{Ma}$ ) landslides. Note that the coast where we infer young slides has very narrow shelves, despite the long-term erosion (> $3 \mathrm{Ma}$ ). Background shaded bathymetry from EMODnet portal (https://www.emodnet-bathymetry.eu/).

\subsection{Field data}

Critical to our objectives are: (1) the attitude of lava flows in the older and younger

volcanic complexes (to constrain volcano geometry, and detect major unconformities and missing volcano flanks); (2) the composition and distribution of sediments in the sedimentary complex, and the geometry of its base (to detect landslide scars and tsunami deposits); (3) the original and current position of sub-aerial and submarine rocks (to analyse vertical displacements); (4) the distribution and attitude of dykes, and geometry and kinematics of faults (to infer stresses); and (5) the shape of the marine shelves (to detect recent collapses).

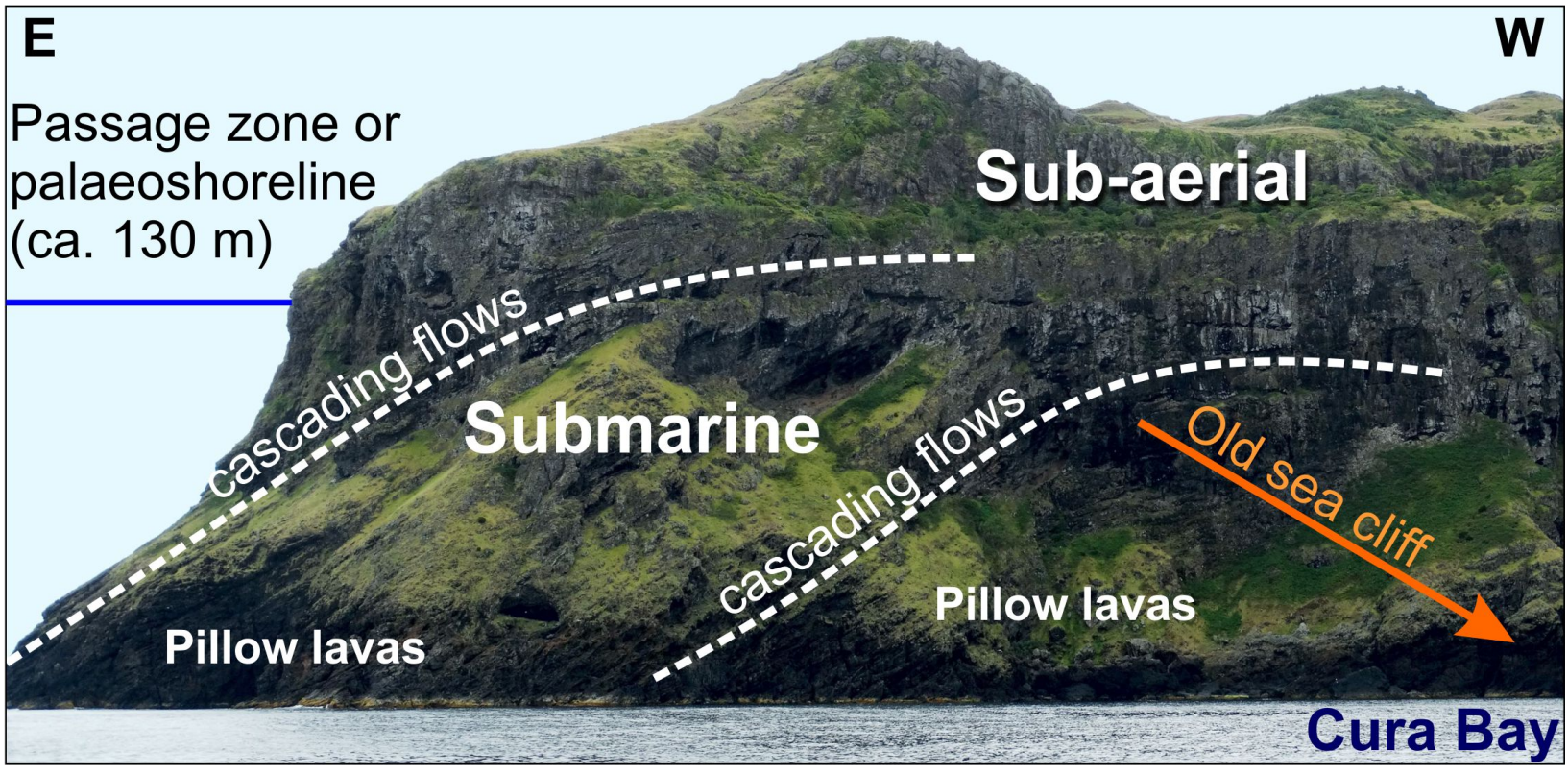

Figure 3. Photograph showing the geometry of lava flows at Baía do Cura in eastern Santa Maria (see Fig. 2 a for location). From the geometry, we deduce that flows cover an old sea cliff to the west (orange arrow).

In an abandoned quarry NE of the north end of the airport runway (site of sample SM16B, Fig. 2a), the sub-aerial OVC overlies steeply eastward-dipping submarine flows intruded by dykes, which might correspond to an OVC passage zone (palaeoshoreline) or to the 
basement complex. The OVC occupies the western half of Santa Maria, and the lava flows dip gently to the W or WSW (Fig. 2 and Fig. S-1). In contrast to the westerly dip in the OVC, the dip of the unconformity above the OVC is to the east. This unconformity is covered by the Intermediate Sedimentary Complex (ISC), which, at its base, shows chaotic conglomerates composed of polygenetic, large, poorly sorted and poorly rounded boulders (Serralheiro, 2003; this study). To the east, the ISC may pass into marine conglomerates. Towards the top, the sediments become finer and the carbonate component increases. Filling the space removed from the original OVC (east flank), and lying unconformably on the ISC, is the Young Volcanic Complex (YVC), which is initially composed of submarine lava flows, and later of sub-aerial lavas as the volcano emerged out of the ocean. Submarine and sub-aerial lava flows dip to the west all along the southern and northern Santa Maria coasts. Eastern Santa Maria has a great number of Strombolian cones, the lava flows of which dip gently to the east and west. On the eastern coast, passage zones (palaeoshorelines) occur where gently dipping sub-aerial flows pass into steeply dipping submarine flows (Fig. 3).

At Pedreira do Campo (site of sample SMA16O in Fig. 2a), the submarine YVC is seen to lie conformably on the fossiliferous marine ISC through hyaloclastites (Fig. 4), or perhaps with "slight erosion prior to the deposition of the volcanic sequences above" as recognised by Ramalho et al. (2017). From the nature of the contacts between marine sediments and underlying sub-aerial OVC (major unconformity covered with thick chaotic debris deposit), and the overlying submarine YVC (conformable with apparently similar marine environment), we infer that the age of the fossils is close to the age of the pillow lavas dated here (ca. 3.12 Ma). 

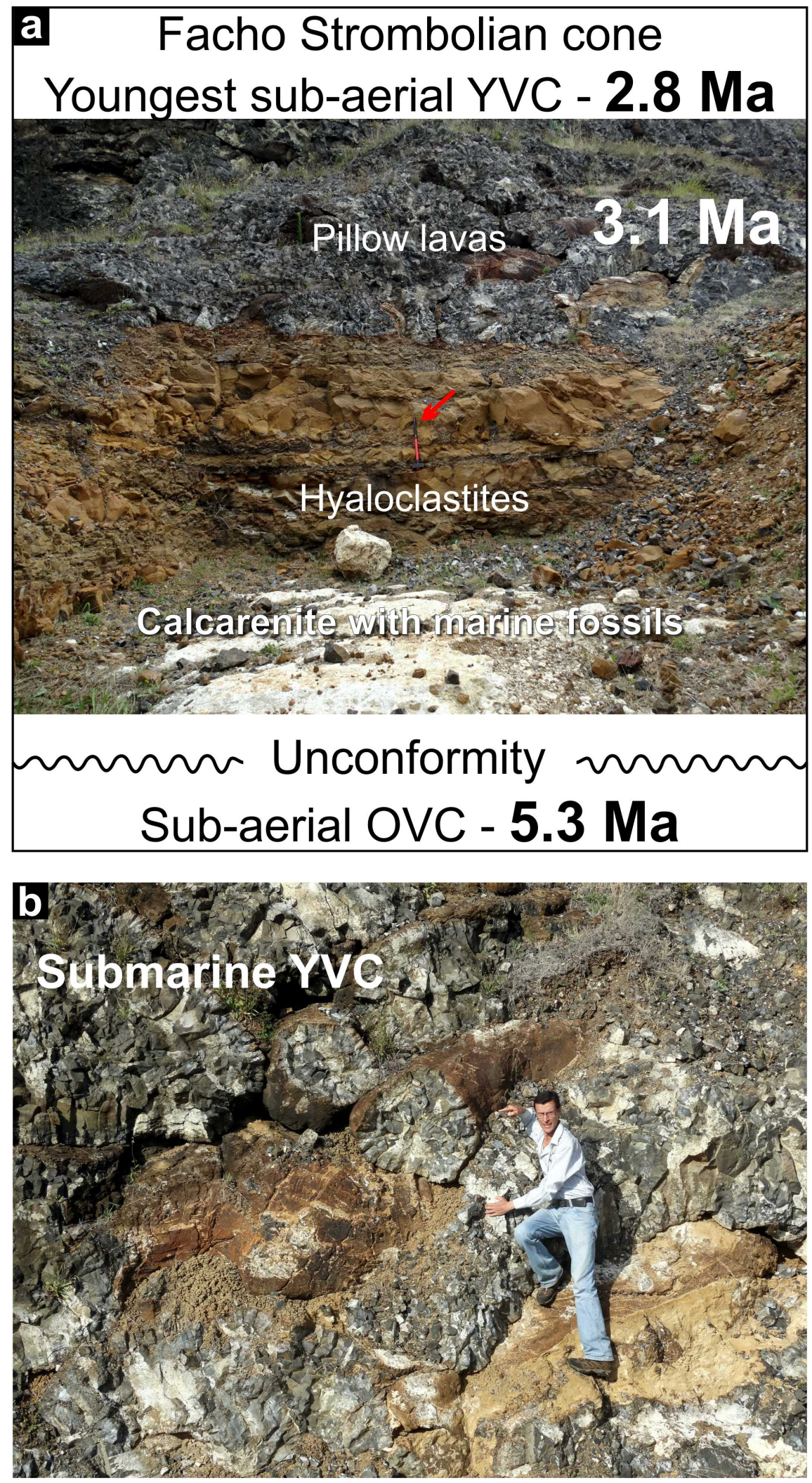

Figure 4. Images of the outcrop at Pedreira do Campo, where we collected sample SMA16O (see Fig. 2 a for location). (a) - contact between pillow lavas, hyaloclastites and calcarenite with marine fossils, all showing a marine setting of deposition. No appreciable unconformity, e.g. erosion surface or angular unconformity, was observed in these outcrops. (b) - detail of collected pillow lavas. Red arrow in (a) points to sledgehammer (ca. $1 \mathrm{~m}$ long handle) for scale. Geologist on outcrop in (b) is $180 \mathrm{~cm}$ tall. 

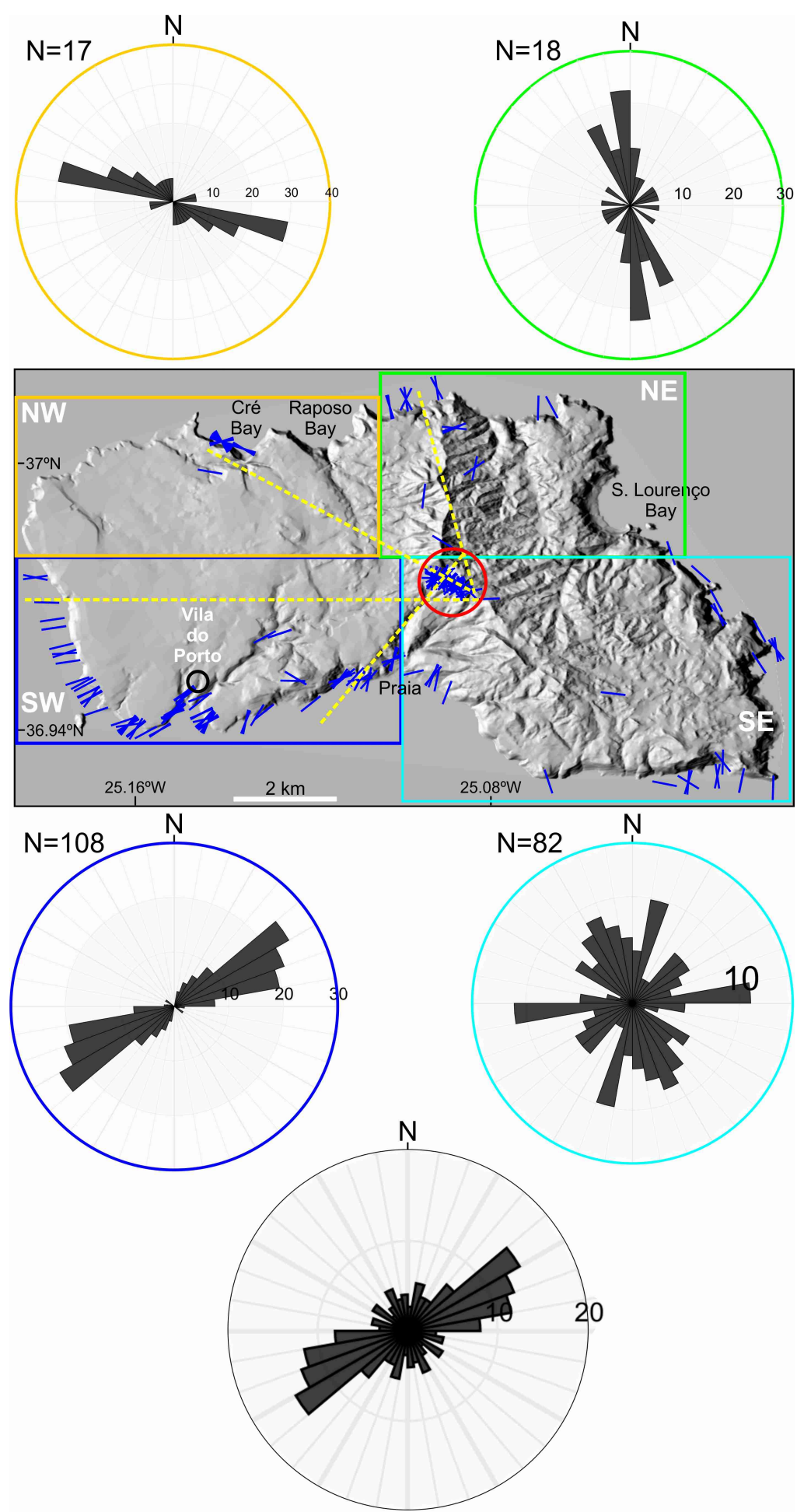

Figure 5. Distribution and attitude of dykes in Santa Maria (blue short lines), and statistics of dyke attitude by quadrants (coloured stereoplots) and total (stereoplot at the bottom). Note that dykes in the OVC (SW, NW and NE quadrants) converge to a small triangular area, marked with a red circle. 

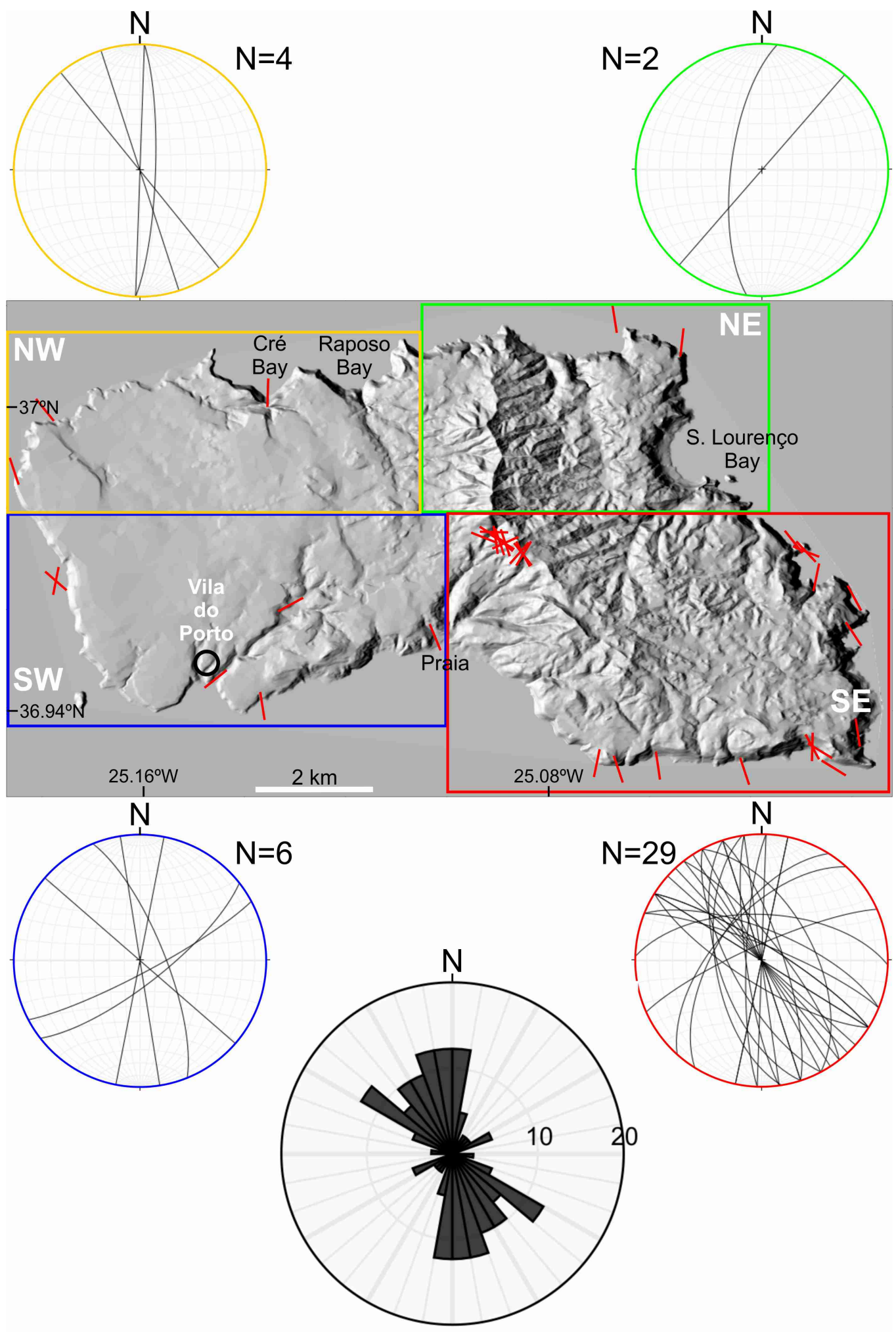

Figure 6. Heterogeneous distribution of faults in Santa Maria. Compare with Fig. 5 for relationships between dykes and faults.

Dykes show a heterogeneous distribution around the island, with the greatest density of 
dykes in the SW quadrant, and the least dykes in the NW quadrant. There is an overall dominant ENE-WSW trend to their orientation within the OVC, which is largely due to the dominant SW quadrant. Dykes older than the YVC are radial (cf. Fig. 5), and there is a convergence of these older dykes towards a triangular area (inside red circle in Fig. 5), which we infer to have been the approximate position of a major feeding centre for the OVC. A high concentration of dykes with different orientations can be observed within a very small area in the YVC $\left(1-2 \mathrm{~km}^{2}\right.$, inside red circle in Fig. 5), which we interpret as a main feeder for the YVC, which is coincident with the inferred main feeding centre for the OVC. In the southern YVC (i.e. over most of the SE quadrant where there is only YVC), the dykes show a generally scattered trend, but a NW to N main trend is apparent. In the northern YVC (i.e. over part of the NE quadrant on the coast and inland where there is only YVC), the young dykes trend mostly N-S to NNE-SSW. Young dykes in eastern Santa Maria have a dominantly curved pattern (concave eastward) in the YVC, gradually changing from NW-SE in the south to NNE-SSW in the north (Fig. S-3).

Faults have a heterogeneous distribution around the island (Fig. 6), with most faults outcropping in the SE quadrant, although the number of faults in the NE quadrant might be significantly underestimated (due to the poor outcrop conditions, even on the coast). There are many more faults in the eastern half of the island, which is dominated by the YVC, implying a heterogeneous distribution in both space and time. Faults have an overall dominant NNW-SSE trend (Fig. 6). Most of the observed tectonic faults have only small displacements $(<10 \mathrm{~m})$, but a few have significant (> $50 \mathrm{~m}$ ) displacements (Figs. 7, 8, S-5). These higher displacement faults trend mostly around NNW-SSE, and dip either to the east or to the west. The striations are dipslip, or steeply plunging to north or south, thereby defining dominant normal faulting with a small strike-slip component (either dextral or sinistral). Two new pairs of conjugate faults have been identified that define, as named here, the Praia and Maia Grabens (Figs. 1c and 7). The Praia Graben in central Santa Maria is bounded to the west by an eastward-dipping fault (Fig. 7), 
and to the east by a westward-dipping fault. This can be inferred from the different altitude of the

base of the ISC in the graben (ca. $50 \mathrm{~m}$ ) and on the eastern shoulder (ca. $85 \mathrm{~m}$ ), where it should does not seem to cut through the ca. 3.6 Ma lava flows.

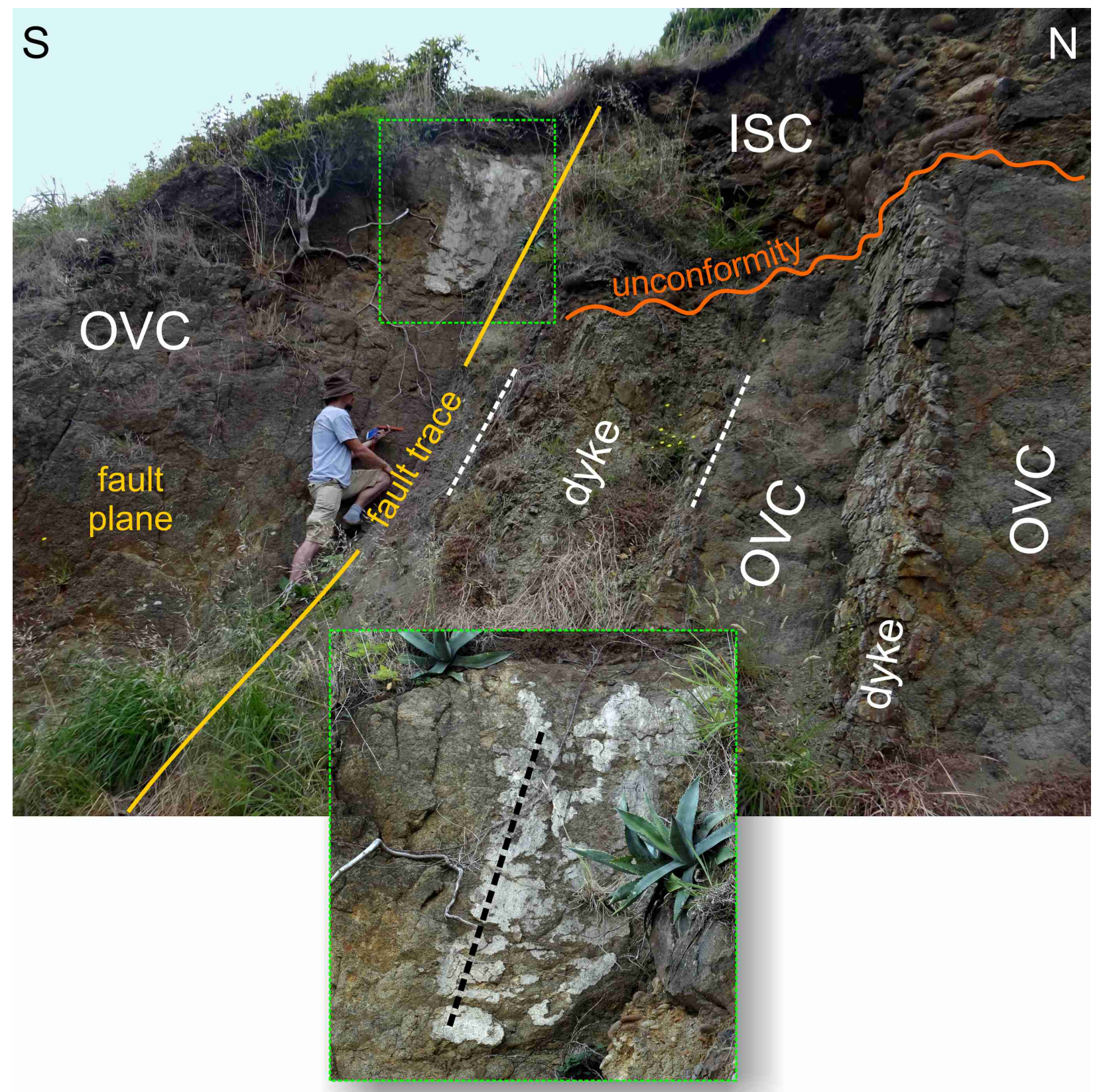
$N 158$ and dips $70^{\circ}$ toward the observer (ENE), and is normal dextral given the plunge of the 
striations (dashed black line zoomed on the inset at the bottom) and the displacement of the unconformity. The dykes strike N60 and dip $70^{\circ}$ to the south, and do not propagate through the major unconformity into the Intermediate Sedimentary Complex (ISC, here composed of chaotic conglomerates). OVC-Old Volcanic Complex. Geologist on outcrop is $183 \mathrm{~cm}$ tall.

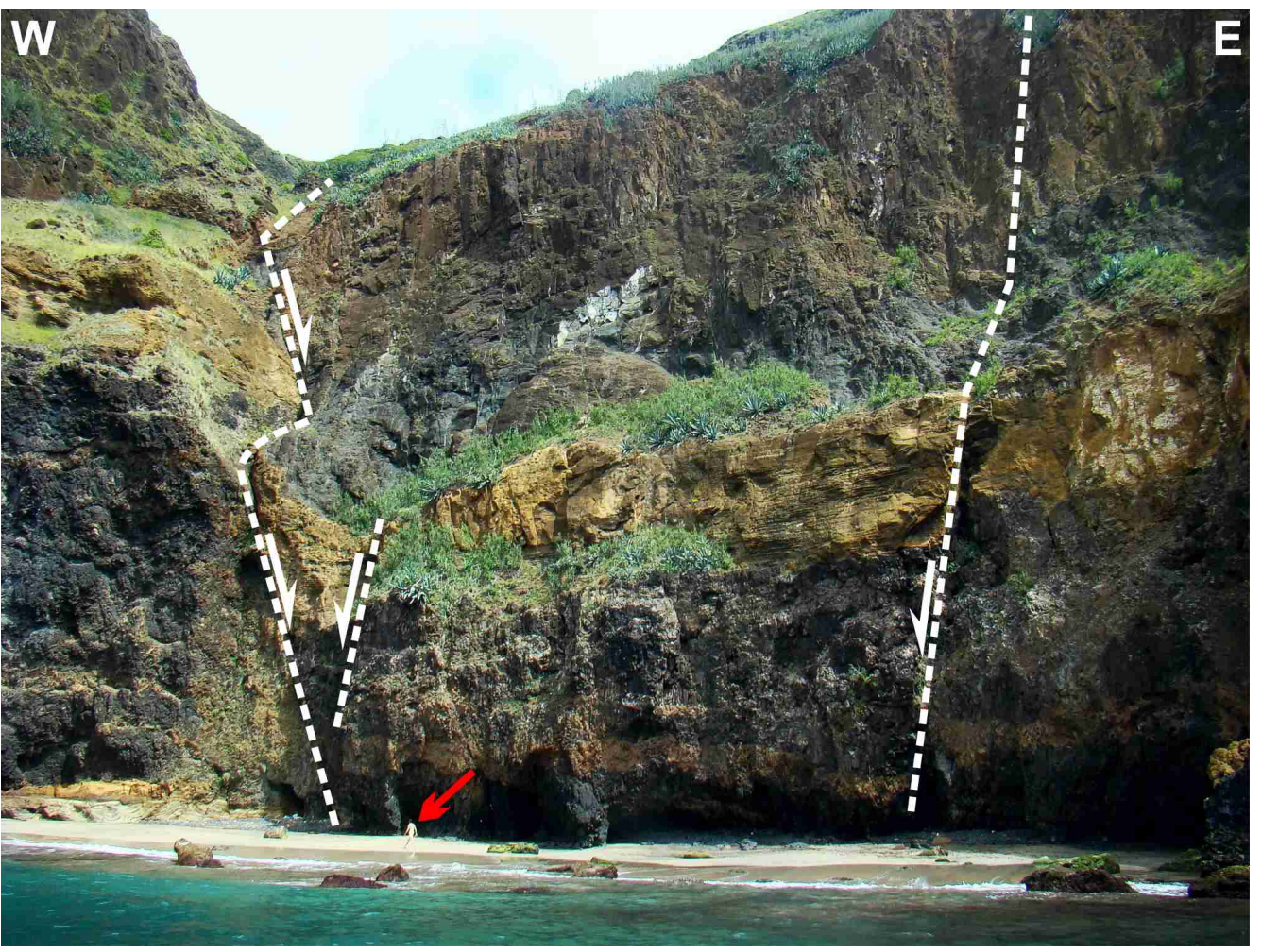

Figure 8. Normal faults dipping to the east (main fault) and west (minor), outcropping on the central southern coast and defining the west boundary of the Maia Graben. Red arrow points to geologist (180 cm tall) on the beach for scale. 


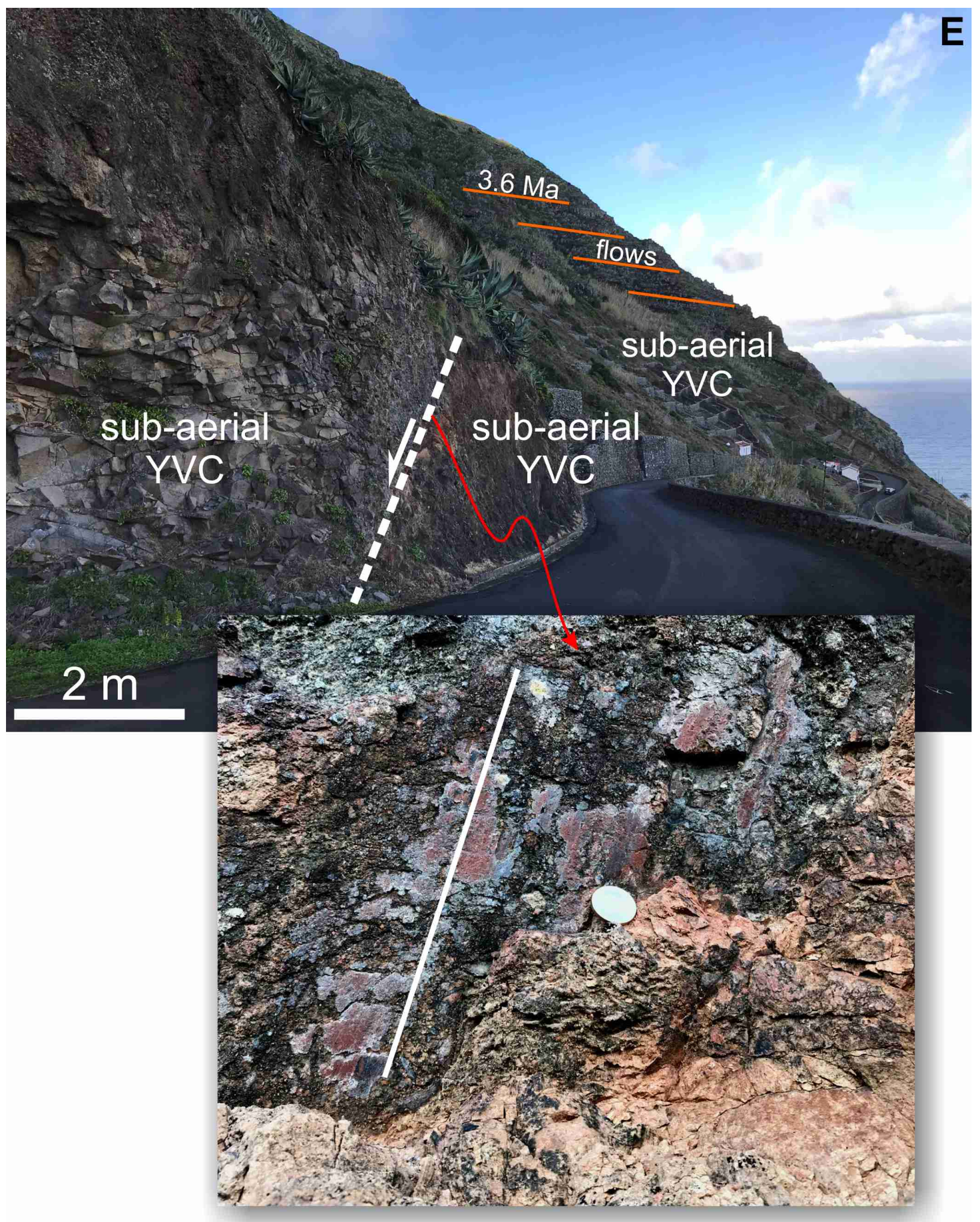

Figure 9. Photo of fault outcropping upslope the village of Maia (Fig. 10 for location), eastern Santa Maria, trending $N 170$ and dipping $70^{\circ}$ to the west. The striations (highlighted by white line on inset) and shear criteria indicate dominant normal faulting with a sinistral strike-slip component. Note that the fault only affects the Young Volcanic Complex (YVC), but does not seem to cut through the ca. 3.6 Ma lava flows. 
Table 1 - Summary of the new ages obtained in this study, with uncertainty at $1 \sigma$ confidence level. Final age in bold character, obtained by weighing by the amount of radiogenic $\mathrm{Ar}\left({ }^{40} \mathrm{Ar} *\right)$.

\begin{tabular}{|c|c|c|c|c|c|c|c|}
\hline $\begin{array}{l}\text { Sample } \\
\text { reference }\end{array}$ & $\begin{array}{c}\text { Longitude } \\
(\mathrm{W})\end{array}$ & $\begin{array}{c}\text { Latitude } \\
(\mathrm{N})\end{array}$ & $\mathrm{K} \%$ & ${ }^{40} \mathrm{Ar} *(\%)$ & $\begin{array}{c}{ }^{40} \mathrm{Ar} *\left(10^{12}\right. \\
\mathrm{at} / \mathrm{g})\end{array}$ & Age (Ma) & $\begin{array}{c}\text { Uncertainty } \\
1^{\sigma}(\mathrm{Ma})\end{array}$ \\
\hline \multirow[t]{3}{*}{ SMA16K } & 25.11723 & 37.00413 & 1.645 & 15.9 & 10.30 & 5.99 & 0.09 \\
\hline & & & & 15.0 & 10.35 & 6.02 & 0.09 \\
\hline & & & & & mean & 6.00 & 0.09 \\
\hline \multirow[t]{3}{*}{ SMA16G } & 25.18262 & 36.99545 & 1.510 & 74.1 & 8.706 & 5.51 & 0.08 \\
\hline & & & & 76.5 & 8.689 & 5.50 & 0.08 \\
\hline & & & & & mean & 5.51 & 0.08 \\
\hline \multirow[t]{3}{*}{ SMA16B } & 25.16627 & 36.98736 & 1.474 & 50.1 & 8.361 & 5.42 & 0.08 \\
\hline & & & & 51.0 & 8.383 & 5.44 & 0.08 \\
\hline & & & & & mean & 5.43 & 0.08 \\
\hline \multirow[t]{3}{*}{ SMA16O } & 25.134978 & 36.946560 & 1.178 & 25.6 & 3.867 & 3.14 & 0.05 \\
\hline & & & & 24.2 & 3.818 & 3.10 & 0.05 \\
\hline & & & & & mean & 3.12 & 0.05 \\
\hline
\end{tabular}

\section{3. $K$-Ar dating}

The new K-Ar ages obtained in this study range between $3.12 \pm 0.05 \mathrm{Ma}$ and $6.00 \pm 0.09$ Ma (Table 1 and Fig. 10). They are consistent with the available stratigraphic controls and with previous $\mathrm{K}-\mathrm{Ar}$ and $40 \mathrm{Ar} / 39 \mathrm{Ar}$ ages measured on separated groundmass (Sibrant et al., 2015a; Ramalho et al., 2017). The new age of $6.00 \pm 0.09$ Ma here obtained on sample SMA16K collected at Baía do Raposo (Fig. 10), just below the ISC, extends the age of the OVC up to ca. 6.0 Ma. Previous and new ages make it possible to better constrain the stratigraphic sequences in critical sections, and to better correlate well-exposed sections in different parts of the island (Fig. 10). The 6.0 Ma age in the OVC shows that the Cabrestantes (dated by Ramalho et al., 2017, at ca. 6.0 Ma) and Porto volcanic cones belong to the OVC. They are not independent units as defined by Serralheiro et al. (1987). The ca. 3.1 Ma age shows that the fossil deposits have different ages at different altitudes and from east to west ( $>4.8$ Ma to the east at sea level, and ca. 3.1 Ma to the west and at $100 \mathrm{~m}$ altitude), thus helping in reconstructing the growth of the 
YVC and the associated vertical displacements of the island.

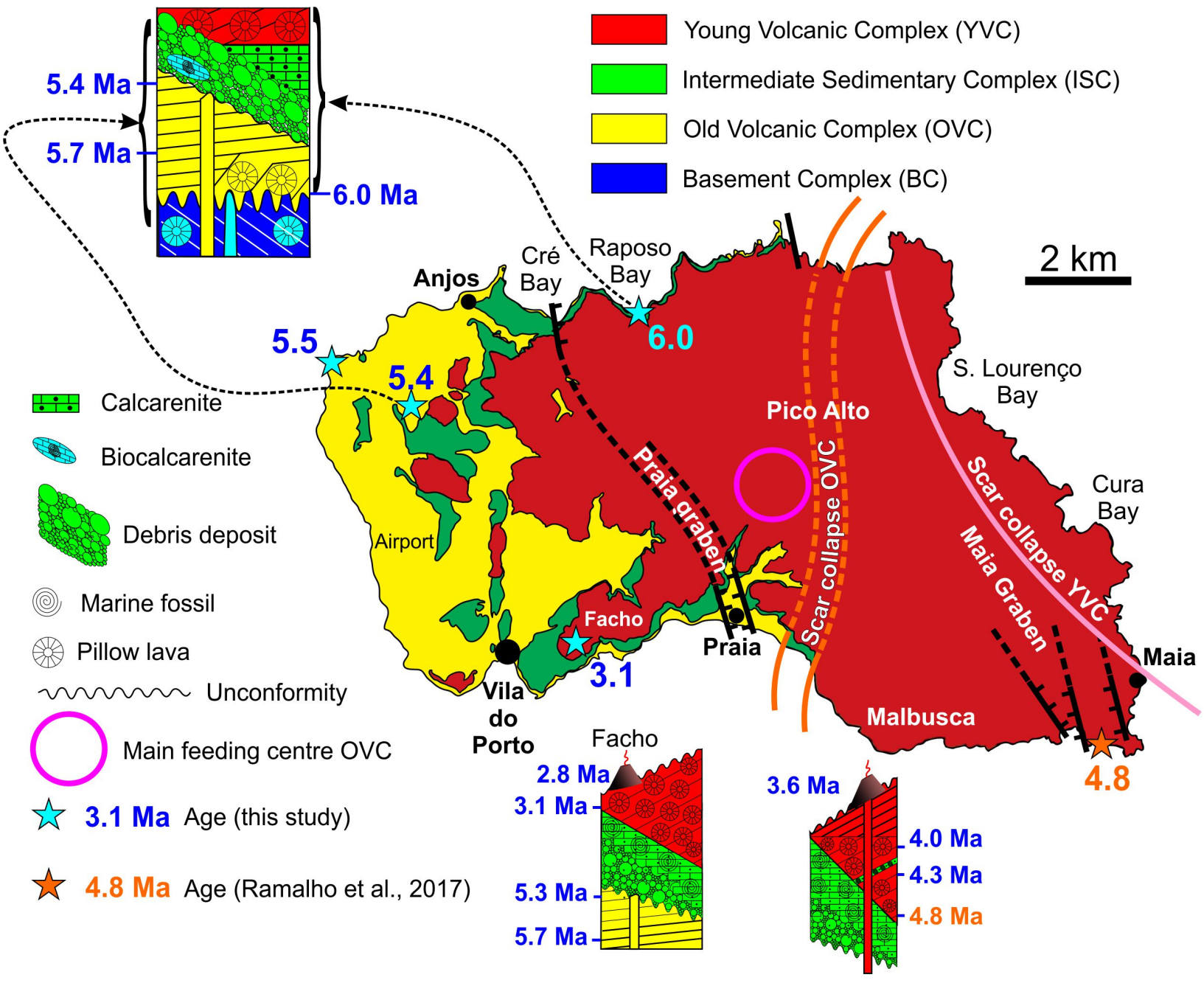

Figure 10. Proposed geological map with new stratigraphy calibrated by ages reported in Sibrant et al. (2015a-ages in blue on the logs, and also cyan on the map), Ramalho et al. (2017 - ages in orange) and this study (light blue stars). Also note the newly proposed position of the two large-scale landslide scars and of the two recognized main grabens. In the logs, vertical lines represent dykes, and oblique lines represent dip of lava flows.

\subsection{Gravitational instability in Santa Maria}

Adding to the works of Marques et al. (2013b) and Sibrant et al. (2015a), we can now give a much narrower age interval and location for the first and second flank collapses. Marques et al. (2013b) and Sibrant et al. (2015a) proposed an age of between 5.3 and 4.3 for the first collapse, and here we narrow the age interval down to 5.2-4.9 Ma. Marques et al. (2013b) and Sibrant et al. (2015a) did not give a specific location for the faults produced by the first flank collapse, which we do here. The first flank collapse at ca. 5 Ma has been inferred from the short 
time span between first and second shield volcanoes (ca. $0.3 \mathrm{Ma}$ ) and the preservation of only the western flank of the first shield volcano (Marques et al., 2013b; Sibrant et al., 2015a; present study). The location of the first collapse is here deduced from fieldwork data, the position of the main feeding centre inferred from radial dykes, and the geological maps shown in Fig. 11. On the south coast (Fig. 11a), the sub-aerial OVC is in lateral contact with the ISC from sea level to ca. $100 \mathrm{~m}$ altitude (solid black line). Further inland, the sub-aerial OVC has a direct contact with the sub-aerial YVC at ca. $170 \mathrm{~m}$ altitude (dashed black line), or through an intervening ISC. These relationships are summarized in the X-Y cross-section shown in Fig. 11c. On the northern coast (Fig. 11b), the geological configuration is similar to that mapped on the southern coast, but with a more complex structure, i.e. the landslide fault apparently has a graben-horst structure, instead of the two, simple east-dipping normal faults inferred for the southern coast. Here we better constrain the age of the collapse at ca. 5.0 Ma, using the youngest OVC age (ca. 5.2 Ma) and the oldest YVC age (ca. 4.9 Ma). This allows us to infer a collapse of the summit and eastern flank of the first shield volcano, delimited by a concave fault running approximately N-S from the central/south coast to the NE coast of Santa Maria (Fig. 11).

Three pieces of evidence allow us to infer a second collapse. First, the position of younger (3.5-3.7 Ma) YVC cones on a surface that is concave to the east, which is the opposite of the general rule for well-preserved shield volcanoes, where parasitic cones sit on a convex conical surface. The adventive cones are therefore unconformable on the westward-dipping older (> 4.0 Ma) YVC, and their lava flows dip gently to the west and the east. Second, the summit crater or caldera is missing. Third, the passage zones in eastern Santa Maria (Fig. 3), which are made up of lavas flowing from the parasitic cones. The passage zone is here interpreted as the result of lavas flowing over a steep scarp (landslide scarp?), which must lie deeper to the west. Given that on the south and north coasts lavas dip to the west, and unconformable east-dipping lavas only occur on the east coast, we conclude that the second landslide fault must lie between 


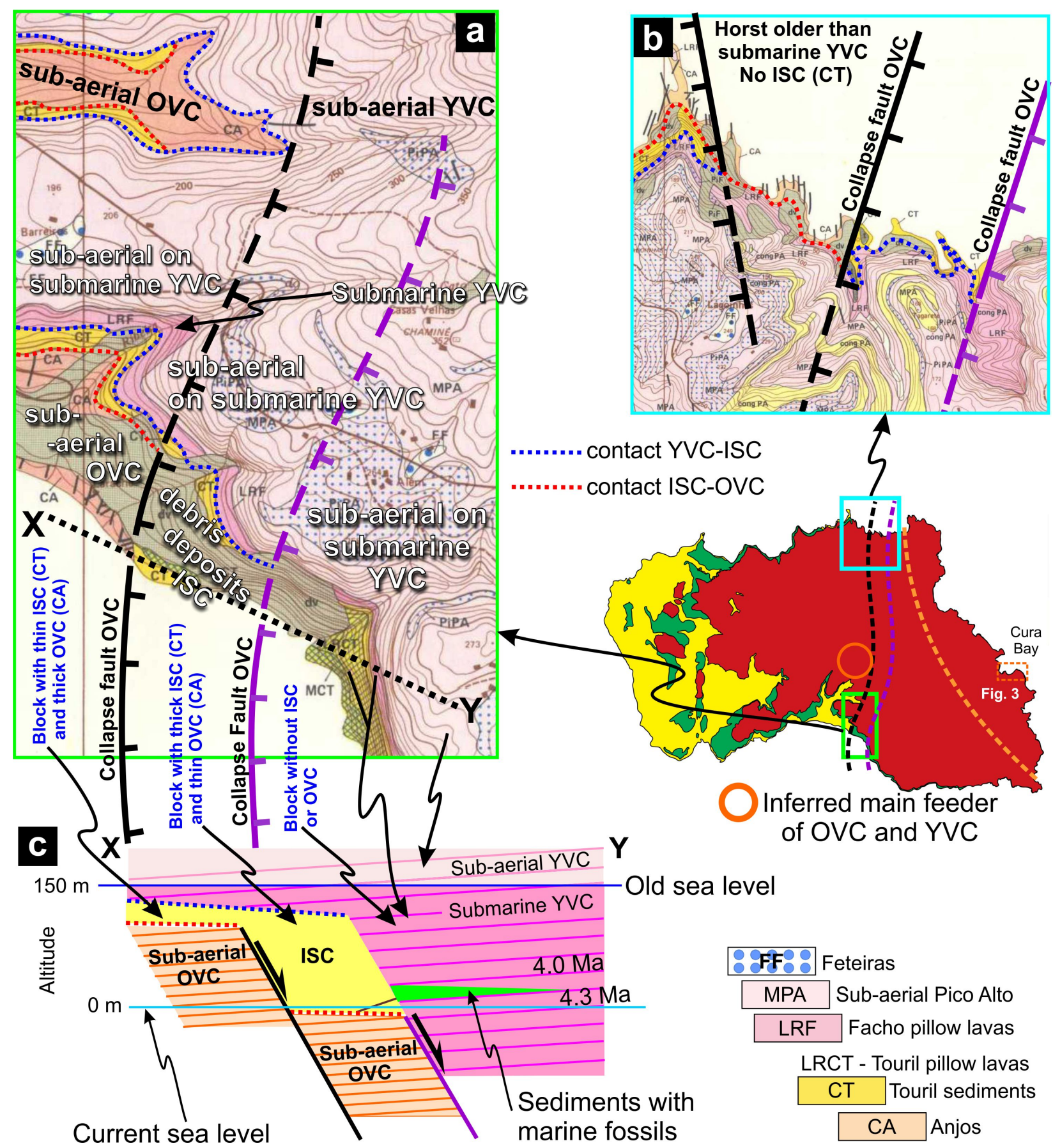

Figure 11. Panels (a) and (b) are extracts of the geological map of Serralheiro et al. (1987) with our interpretation of the location of the main landslide faults affecting the OVC, based on the distribution of the OVC, the ISC and the YVC, as represented in the X-Y cross-section in panel (c). Note that we have put LRCT and LRF together as the submarine part of the YVC. Also note that the old landslide faults are drawn where the OVC abruptly ends against the ISC and/or YVC (black line), and where the ISC abruptly ends against the submarine YVC (magenta line). Red lines plunging to the west in (c) represent lava flow dip. 


\subsection{Gravitational instability around Santa Maria Island}

Given that LSMW in the area could be related to the tectonic evolution of the ATJ, as suggested for Santa Maria, it is important to have a complete view of LSMW around the island. At least one submarine slide has been recognized near Santa Maria in the Monaco Bank (Weiß et al., 2016) (Fig. S-5). Weiß et al. (2016) interpreted the slide using high-resolution bathymetry and seismic reflection, and concluded that it occurred as a slow LSMW event. In Fig. S-5b we re-interpret the Monaco Bank slide regarding the faults and the original volume/shape of the slide block. We used shaded relief bathymetry and a bathymetric profile to interpret the landslide faults, mainly based on the scars observed on the bathymetry and the distribution of the debris. We reconstructed the original wedge, the volume of which compares very well with the volume of the debris deposit. From the ratio $(10 \mathrm{~km} / 2 \mathrm{~km}=5)$ between the distance travelled by the debris $(10 \mathrm{~km})$ and the Monaco Bank height $(2000 \mathrm{~m})$, we infer that the slide was relatively slow, but maybe not as a slump as Weiß et al. (2016) suggested.

\subsection{Tsunami deposits}

Several conglomeratic deposits occur on Santa Maria, but here we only focus on two that are potential tsunami deposits (Figs. S-6 and S-7). The most widespread deposit is the one blanketing the unconformity atop the OVC and sealing the old dykes. This polygenetic chaotic debris deposit is very well exposed on the road into Praia from the west (Fig. S-6). It contains boulders from meters to centimetres in size, and comprises two main layers (Fig. S-6a): the bottom layer contains mostly well-rounded large boulders in a calcarenite matrix (Fig. S-6c), and the top layer contains smaller and more angular boulders in a grey clay matrix (Fig. S-6b). Moreover, the bottom layer comprises well-polished pebbles (Fig. S-6d), typical of a wind and sand polishing process in low-altitude coastal areas. From the nature of the matrix and pebble roundness and polish, we infer that the bottom deposit originated in the sea (tsunami runup), and 
the top deposit originated in land (tsunami backwash).

A smaller deposit occurs at site SMA16B (see location in Fig. 2) and is shown in Fig. S7. This deposit is also polygenetic, chaotic, very poorly sorted with large boulders in a matrix of pebbles, gravel, sand and clay. This deposit includes large blocks of marine sediments (Fig. S7b) and pillow lavas (Fig. S-7c) attesting to its marine origin. Unfortunately, the relationship with the surrounding sub-aerial OVC is not clear. If it were to sit unconformably on the OVC and below the YVC, then it would have the same age as the deposit described above.

\section{Discussion}

\subsection{Stratigraphy calibrated by geochronology}

Given the similarity of the ages (ca. $6 \mathrm{Ma}$ ) of small and scattered outcrops of Porto, Cabrestantes (dated by Ramalho et al., 2017 at ca. 6 Ma) and Baía do Raposo (here dated at ca. 6 Ma), we consider the Porto and Cabrestantes units as OVC. The new age at Baía do (Bay of) Raposo (ca. $6 \mathrm{Ma}$ ) better constrains the oldest age of the OVC, and shows the consistency with the general dip of the OVC flows to the west.

In addition, the Touril Complex, considered by Serralheiro et al. (1987) to include subaerial and submarine lava flows and sediments, is here reduced to the sedimentary rocks, and is renamed Intermediate Sedimentary Complex (ISC). The section at Pedreira do Campo (Fig. 4) shows the typical transition sequence from the OVC to the Young Volcanic Complex (YVC), through an unconformity between the OVC and sediments, which are conformably overlain by the YVC. Therefore, the sub-aerial lava flows belong to the OVC and the submarine flows belong to the YVC. We note that (Fig. S-8) extrapolation of the age of dated pillow lavas at Pedreira do Campo (Fig. S-8c) to similar settings (Fig. S-8b and d) along the same yellow unit to the east (CT, Complexo do Touril of Serralheiro et al., 1987) leads to major inconsistencies. Furthermore, the submarine lavas (LRF) here dated at 3.1 Ma at Pedreira do Campo (Fig. S-8c) 
cannot be overlain by lava flows that are older (Fig. S- $8 \mathrm{~b}$ and d), and the CT sediments at Pedreira do Campo (ca. 3.2 Ma) cannot be the same as the CT sediments to the east atop Praia (Fig. S-8a) and at Malbusca (ca. 4.1 Ma) in Fig. S-8d. Therefore, there must also be a scarp where a thick black line marked F is drawn in Fig. S-8b, because the OVC (CA on the map) ends abruptly at sea level (whereas it reaches $150 \mathrm{~m}$ altitude immediately to the north). Likewise, the chaotic debris deposit (CT) also ends here, where the conglomeratic deposit passes into submarine lavas of the YVC (LRCT on the map in Fig. S-8d). This scarp/fault has to be older than the CT because it does not cross-cut it.

We also find that the submarine Facho Complex cannot be below the Pico Alto Complex (4.8 to $2.8 \mathrm{Ma}$ ), as proposed by Serralheiro et al. (1987), because the Facho Volcano is subaerial, and it is the youngest volcanism on the island, dated by Sibrant et al. (2015a) at ca. 2.8 Ma. The submarine lavas attributed to Facho actually lie below the Facho Volcano, and comprise the submarine volcanism of the YVC (4.8 to 3.1 Ma). Given the continuous (no unconformities recognized) age spread of submarine lava flows (4.8 to 3.9 Ma; Sibrant et al., 2015a; Ramalho et al., 2017), sampled in the Touril, Facho and Pico Alto complexes, there is no argument for attributing them to three distinct volcanic units. We therefore group them together as the early submarine stage of the YVC.

Finally, we find that the Feteiras Formation ("feteiras" means "the place where fern grows"; cf. Fig. S-9) is simply deposits from parasitic Strombolian cones that belong to the YVC, as indicated by the radiometric ages of Sibrant et al. (2015a) and Ramalho et al. (2017). The "pyroclasts" attributed to Feteiras are actually not pyroclasts, but instead a soil resulting from deep in-situ weathering of lava flows (Fig. S-9). The Feteiras Formation also cannot be stratigraphically above the Facho Complex, as proposed by Serralheiro et al. (1987), because the cones attributed to this unit are much older (ca. 3.6 Ma; Sibrant et al., 2015a) than Facho (ca. 2.8 Ma; Sibrant et al., 2015a). 
449 Basement Complex, which corresponds to the seamount stage (prior to $6 \mathrm{Ma}$ ); (2) the Old

450 Volcanic Complex, which built the first sub-aerial shield volcano (maybe initially submarine; 6

451 to $<5.3 \mathrm{Ma}$ ); (3) the Intermediate Sedimentary Complex, which comprises mixed sub-aerial and

452 submarine conglomerates overlain by marine calcarenites with abundant fossils $(<5.2$ to $>3.1$

$453 \mathrm{Ma}$; (4) the Young Volcanic Complex, which built the second shield volcano, initially

454 submarine with intercalated fossiliferous sediments, and gradually passing into sub-aerial, with

455 late parasitic cones on top ( $>4.8$ to $2.8 \mathrm{Ma}$ ). These four complexes are each separated by major

456 unconformities as shown in Fig. 12. 

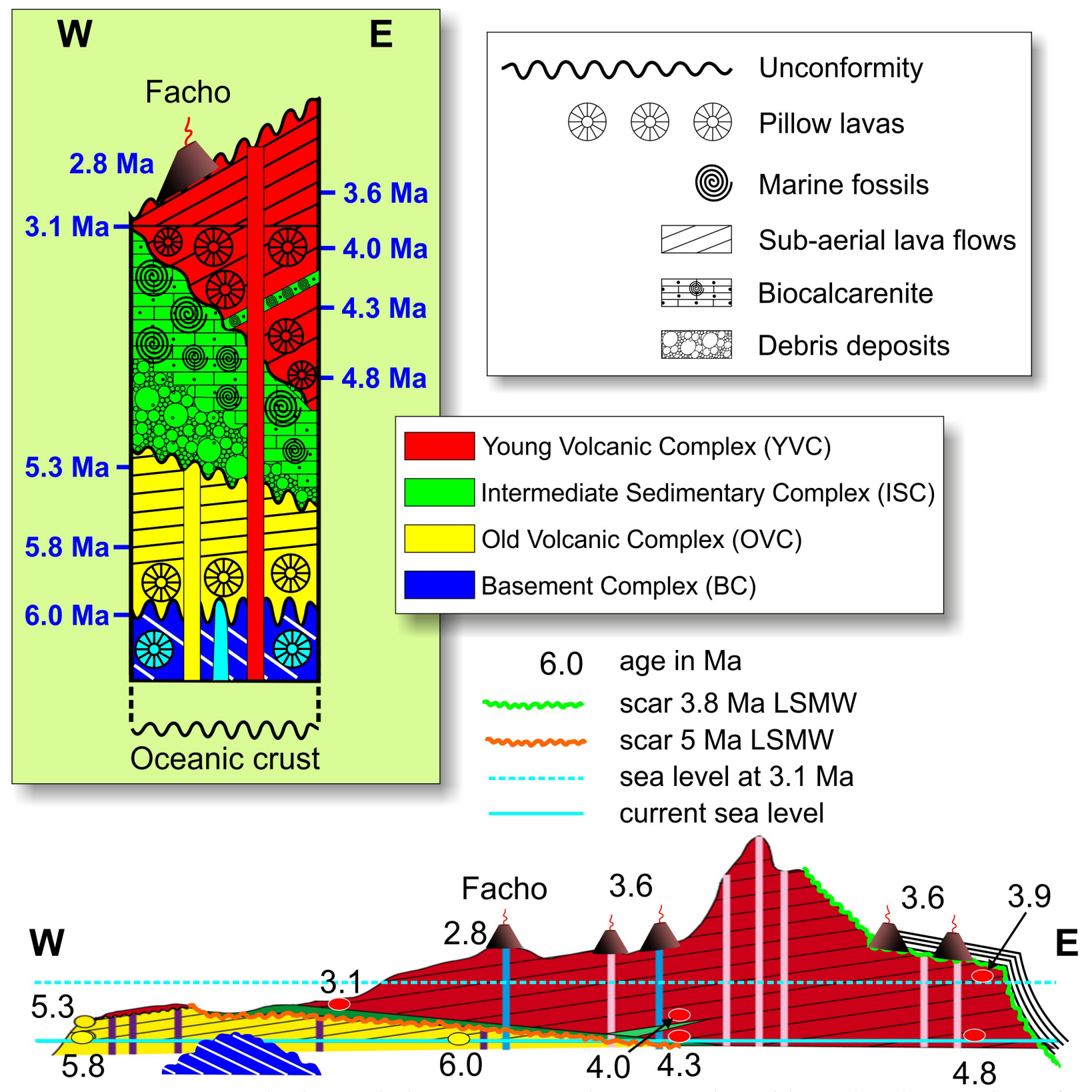

Figure 12. Top panel - log with the new proposed stratigraphy calibrated with $\mathrm{K}$-Ar data of Sibrant et al. (2015a) and present study, and ${ }^{40} \mathrm{Ar}{ }^{\beta 9} \mathrm{Ar}$ data of Ramalho et al. (2017). Bottom panel-geological cross-section summarizing all field and geochronological data. Note the consistency between lava flow dip and younging to the west at similar altitude, and upwards, in both $O V C$ and $Y V C$. Also note that the young volcanic cones in the east lie unconformably on the basal YVC, through a LSMW scar, and in the west they lie conformably on the basal YVC as parasitic cones.

From the stratigraphic logs shown in Fig. 10 and 12, and supported by the new ages (see also Fig. S-8), it is apparent that the fossil deposits cannot all have the same age. In fact, there is a difference of ca. 1 Ma between the sediments at Malbusca Point (ca. 4.2 Ma) and at Pedreira do Campo (ca. 3.2 Ma). This has major consequences regarding the palaeontology of the marine 
fossils in Santa Maria (because the use of fossils for stratigraphy and correlation with similar fossils in other parts of the world depends critically on their age), and is vital to the interpretation of the evolution of the island and its vertical movements (especially subsidence during growth of the YVC).

\subsection{Structure, tectonics, strain and stress}

Comparison between Figs. 5 and 6 shows that dykes of the OVC do not follow mapped faults, and the quadrant with the most dykes (SW) is not the one with the most faults. In the YVC, the SE quadrant is dominated by both dykes and faults, where many have similar orientations. From this we infer that this second population of dykes were instead injected into fractures sub-parallel to faults (only locally do dykes intrude actual faults).

Our interpretation of the geometrical, spatial and temporal relationships of dykes and faults is that the stress field changed over time and in space, especially during the transition from the OVC to the YVC, the time of the older flank collapse (ca. $5 \mathrm{Ma}$ ). In support of this, older dykes (> 5.2 Ma) show a bulk radial distribution, similar to what Marques et al. (2019) observed in Fogo Island, Cape Verde, from which we infer the location of the main feeding centre and a radial stress field imposed by the first shield volcano (Marques and Cobbold, 2002). Then, there is a clear dominance of the WSW-ENE trend in the SW quadrant, which includes multipleinjection dykes (cf. Fig. S-2), attesting to preferential NNW-SSE opening (least compressive stress) due to the regional stress field. Next, the younger dykes $(<4.9 \mathrm{Ma})$ show a preferential trend along the NNW-SE to NNE-SSW direction, attesting to preferential ENE-WSW opening. Finally, the faults are mostly normal, heterogeneously distributed in space (across central and eastern Santa Maria), younger than ca. 4.8 Ma, and show a preferential NNW-SSE to N-S trend (ENE-WSW to E-W opening). Dykes older than ca. 5 Ma could be related to the similarly trending East Azores Fracture 
Zone, the old Nubia-Eurasia plate boundary. Instead, dykes younger than ca. 5 Ma could be related to ENE-WSW extension in the last 4.0 Ma (DeMets et al., 2010), and to the rift jump from the East Azores Fracture Zone to the Terceira Rift along several transient, short lived, grabens trending WNW-ESE (Vogt and Jung, 2004). Building on the work of Luís et al. (1994), Vogt and Jung (2004) and Sibrant et al. (2015a), here we can specify that the change in stress field orientation occurred at ca. $5 \mathrm{Ma}$, as supported by our new geochronological data and volcanic stratigraphy.

The trend of the ca. $5 \mathrm{Ma}$ LSMW scar is approximately N-S, at a high angle to the dominant WSW-ENE dyke trend in the OVC, thus excluding a relationship between collapse and dykes. The N-S trend is perpendicular to the far field extension in the eastern Azores (DeMets et al., 2010). Therefore, we suggest that extension could have favoured the localization and the triggering of the two LSMW here proposed. It could also have produced the main grabens identified here. Finally, we propose that a transient Santa Maria Graben started opening at about $5 \mathrm{Ma}$, and was responsible for the flank collapse inferred for Santa Maria at that age. Note that both inferred LSMW occurred along faults striking NNW-SSE to N-S, consistent with extension and the trend of the dykes younger than $5 \mathrm{Ma}$.

\subsection{LSMW events}

Despite the small size of the Azorean islands, several LSMW events have been described recently (Hildenbrand et al., 2012a; Marques et al., 2013b; Sibrant et al., 2014, 2015a, b, 2016; Costa et al., 2014, 2015; Marques et al., 2018; Hildenbrand et al., 2018). Exceptions in the eastern Azores are the islands of Faial (Hildenbrand et al., 2012b; Marques et al., 2014b; Trippanera et al., 2014) and Terceira (Marques et al., 2015; Quartau et al., 2014), where LSMW has not been described (Mitchell, 2003; Casalbore et al., 2015; Quartau et al., 2012, 2015). From the bulk radial distribution of dykes at Santa Maria, we infer the position of 
coincident OVC and YVC main feeding centres on the divide between the eastern and western parts of the island (cf. Fig. 5). If this interpretation is correct, then the summits and eastern flanks of the two shield volcanoes are missing, as can also be deduced from the lava flow geometry (Fig. 12). One can propose an evolution of Santa Maria's morphology based solely on meteoric and marine erosion (Ramalho et al., 2017). However, this view contains three inconsistencies. First, field and geochronological data (lava flow dip and younging to the west) show that both OVC and YVC only have their western flanks preserved. Second, Santa Maria has undergone meteoric and marine erosion, and probably also small-scale landsliding over the last 3.6 Ma, if not longer. This is 10 times longer than the period between the OVC and YVC), but both are still mostly preserved. Third, the difference in age between the lavas of the older and younger shield volcanoes (ca. $0.3 \mathrm{Ma}$ ) is clearly not long enough for meteoric and wave erosion to remove the large amounts of lava flows missing in the older shield volcano (eastern flank and part of the summit). In addition, marine erosion would not have been selective in removing only one half of the shield volcano and preserving the other, especially the half facing the dominant winds (NW, $\mathrm{W}$ and $\mathrm{SW}$ ). Therefore, the alternative is that the missing portion of the original OVC shield volcano has been removed by large-scale sector collapse. The chaotic debris deposit at the base of the ISC could, in part, represent a tsunami deposit associated with this collapse.

The youngest age measured for the OVC is ca. $5.3 \mathrm{Ma}$ (but could be younger further to the west, in the sea) and the oldest age for the YVC is ca. $4.8 \mathrm{Ma}$ (but could be older below current sea level). Therefore, the age of the first flank collapse is bracketed between $<5.3$ and $>4.8 \mathrm{Ma}$, i.e. at around 5.0 Ma. We could not improve the accuracy of the age of the second collapse, but we could provide more detail on its location. The YVC lava flows dip to the west on the southern and northern coasts, but dip to the east on the eastern coast (Figs. 3, 12,13), thus constraining the position of the collapse fault between the SE and NE corners of the island. 


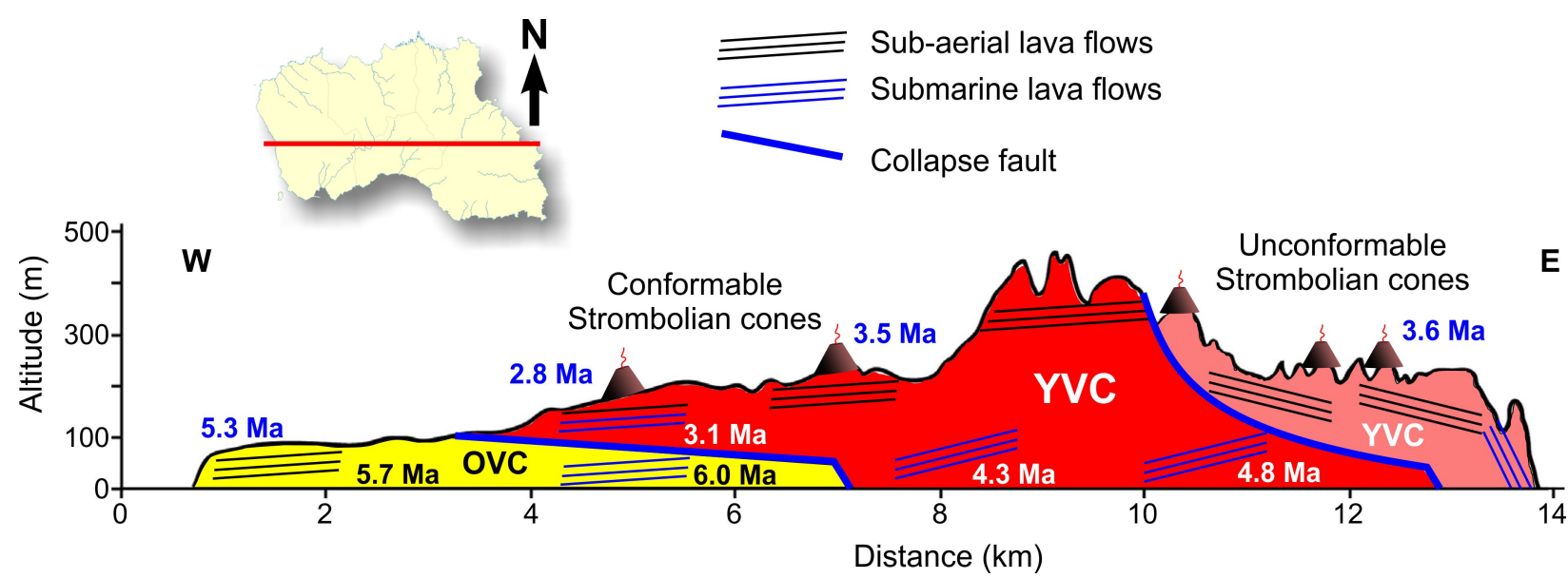

Figure 13. E-W topographic cross-section with drawn geometry of lava flows and position of $L S M W$ scars and young volcanic cones $(<3.7 \mathrm{Ma})$. Note that the cones in the west lie conformably on the western flank of the YVC, as parasitic cones, in great contrast to the cones in eastern YVC that lie at an altitude lower than the top of the west-dipping flows of the basal YVC, therefore unconformable on a surface here interpreted as a LSMW scar.

Given the tectonic position of Santa Maria, its age and the inferred geometry of the landslide scars, the triggering mechanisms of the two inferred LSMW events may have been: (1) high-magnitude earthquakes due to motion in the East Azores Fracture Zone, the Nubia-Eurasia plate boundary in the Azores prior to the jump to the Terceira Rift; (2) NNW-SSE rifting in the ocean floor and dyke intrusion parallel to the inferred landslide scars.

Given that the onshore ISC deposits lie on an eastward-dipping unconformity atop the sub-aerial OVC, and that there is no evidence of a major palaeotopographic relief nearby, we interpret these deposits to be in part the result of a tsunami produced by the first flank collapse.

\subsection{Vertical movements}

The spatial and temporal distribution of sub-aerial and submarine lavas at Santa Maria is good evidence that: (1) either the island has moved vertically by hundreds of meters (stationary sea level), or (2) the sea level has changed by hundreds of meters (stationary island), or (3) both processes acted together. Hypothesis (2) does not seem viable because sea level estimates (Miller et al., 2005) do not show such sea level highstands (ca. $200 \mathrm{~m}$ ) in the period 6 to 0 Ma. 
At Baía da (Bay of) Cré (Fig. S-10), young island uplift has exposed critical outcrops for the analysis of vertical movements of the island, especially the ones that pre-date younger uplift. Sub-aerial lava flows of the OVC currently outcrop from sea level up to ca. $100 \mathrm{~m}$ (red ellipse in

Fig. S-10). This sub-aerial OVC is unconformably overlain by submarine lavas of the YVC from ca. $100 \mathrm{~m}$ up to ca. $200 \mathrm{~m}$ (blue ellipses in Fig. S-10), where a palaeoshoreline exists at ca. 200 $\mathrm{m}$, in the upward transition to sub-aerial YVC. This current position of sub-aerial OVC at $100 \mathrm{~m}$ altitude, and overlain by $100 \mathrm{~m}$ thick submarine flows of the YVC, means that the sub-aerial OVC was submerged by at least $100 \mathrm{~m}$ (the minimum thickness of the sub-aerial OVC) to allow for the deposition of younger submarine flows of the YVC on older sub-aerial lavas of the OVC. This implies island subsidence between ca. 4.9 Ma (oldest YVC submarine flows close to sea level) and 3.1 Ma (youngest YVC submarine flows at ca. $100 \mathrm{~m}$ altitude), with undetermined influence of sea level change. YVC submarine flows found at an altitude of $200 \mathrm{~m}$, and at the contact with overlying sub-aerial YVC flows (palaeoshoreline), indicate a $100 \mathrm{~m}$ thickness of submarine YVC, and that the sea level at the time of deposition of the uppermost submarine lavas of the YVC was at least $200 \mathrm{~m}$ higher than the present day, due to island subsidence after around 4.9 Ma, with undetermined influence of sea level change. The current exposure of the YVC palaeoshoreline at ca. $200 \mathrm{~m}$ altitude also means that uplift by at least 200 m must have occurred since emplacement, with undetermined influence of sea level change.

A similar situation occurs in SW Santa Maria, on the opposite coast of Baía da Cré, where young uplift has exposed YVC submarine lavas unconformably overlying OVC sub-aerial lavas with intermediate thick marine sediments. Again, submarine lavas on top of sub-aerial lavas means that the island was subsiding until at least ca. 3.1 Ma, with undetermined influence of sea level change. The ca. 3.1 to $2.8 \mathrm{Ma}$ age of the pillow lavas WSW of Facho at ca. $170 \mathrm{~m}$ maximal altitude (Fig. 10 for location), where a palaeoshoreline exists at the transition from submarine to sub-aerial YVC, indicates that, prior to younger uplift the island subsided, with 
undetermined influence of sea level change until ca. 3-2.8 Ma. Ramalho et al. (2017, their Fig. 6) estimated subsidence and uplift rates based on a palaeoshoreline located at about 3.5 Ma, but these rates could be significantly different if the palaeoshoreline age is put at ca. $2.8 \mathrm{Ma}$, as indicated by the new age (ca. 3.1 and younger) of the pillows west of Facho (sub-aerial, ca. 2.8 Ma). Besides, 3.5 Ma is only an upper bound, because uplift could have started anytime between that age (or 2.8 Ma in the present study) and present day, in the absence of reliable markers younger than 2.8 Ma. On the other hand, subsidence starting at ca. 5.3 Ma (Ramalho et al., 2017) is not justified, because the first submarine lavas post-dating the sub-aerial OVC lie above an east-dipping major unconformity and are off-set to the east relative to the OVC, which means that they would be submarine even without any subsidence of the island (Fig. 14).

According to the scenario proposed here, subsidence resulted from significant loading by the YVC growth filling the scar of the first collapse (Fig. 14). We can estimate the isostatic effect of constructional loading by assuming Airy isostasy and a maximum $900 \mathrm{~m}$ thickness of the YVC (current $600 \mathrm{~m}+200 \mathrm{~m}$ missing summit $+100 \mathrm{~m}$ estimated below sea level): $\varepsilon=900-\left(900 * \rho_{l} / \rho_{a}\right)=900-900 * 2800 / 3200=900-788=112 \mathrm{~m}$ where $\varepsilon$ is the topography, $\rho_{l}$ is the density of basaltic lavas, and $\rho_{a}$ is the density of the asthenosphere. The result of $112 \mathrm{~m}$ is an upper bound calculation of the isostatic response to constructional loading, therefore capable of explaining the inferred subsidence.

The new age (3.12 $\pm 0.05 \mathrm{Ma})$ obtained on YVC pillow lavas stratigraphically overlying marine carbonates of the ISC at Pedreira do Campo (Fig. 4), and underlying the sub-aerial ca. 2.8 Ma flows of the Facho volcano, indicates a progressive filling of the first collapse scar by the YVC, initially submarine and later sub-aerial, as the YVC shield volcano grew out of the ocean from east to west over a scarp dipping to the east (Fig. 14). Therefore, subsidence would have been active until, at least, ca. 2.8 Ma. Given the topographic position of 4.8 Ma old submarine YVC close to current sea level to the east (location in Fig. 10) and 3.1-2.8 Ma old submarine 
YVC to the west at ca. $170 \mathrm{~m}$, we infer that, similarly to Baía da Cré, at least $200 \mathrm{~m}$ of subsidence occurred between 4.8 and 2.8 Ma. Subsidence rates at Santa Maria cannot be directly compared with the faster subsidence rates estimated for younger islands in the eastern Azores (Hildenbrand et al., 2012a; Marques et al., 2015), because they lie on younger lithosphere, and are thus subsiding faster due to faster lithospheric cooling (Turcotte and Schubert, 2014). They also lie on rifting lithosphere, where Graciosa, Terceira and S. Miguel islands lie inside the Terceira Rift, and Pico, Faial and S. Jorge islands lie in the area of diffuse rifting (Marques et al., 2013a, 2014a, and Miranda et al., 2014), and are thus currently undergoing additional vertical tectonic movements.

Ramalho et al. (2017) concluded that the only viable mechanism able to explain the uplift is crustal thickening by basal intrusions, and argued that uplift in response to the tectonic regime is unlikely because the area is under transtension. From a physical point of view, the argument of transtension is inconsistent with the known mechanics of rifting lithosphere, because rift shoulders are uplifted during rifting (Weissel and Karner, 1989). Although produced by lithospheric extension, rifts are known to have quite high shoulders, which are produced by uplift of rift flanks due to mechanical unloading of the lithosphere during extension and consequent isostatic rebound (Weissel and Karner, 1989). The Terceira Rift is no exception (Marques et al., 2015; Marques et al., 2018), as well illustrated by the topographic profile shown in Figure 10. Typically, magma ponding at the Moho (underplating) or higher (storing in magma chambers) is contemporaneous with volcanism at the Earth's surface, and differentiation during ponding can be responsible for the evolution of lavas from mafic to intermediate as observed in nearby $\mathrm{S}$. Miguel Island. Santa Maria does not show significant differentiation (Beier et al., 2013), which means that magma found easy ways to reach the surface without significant ponding. 

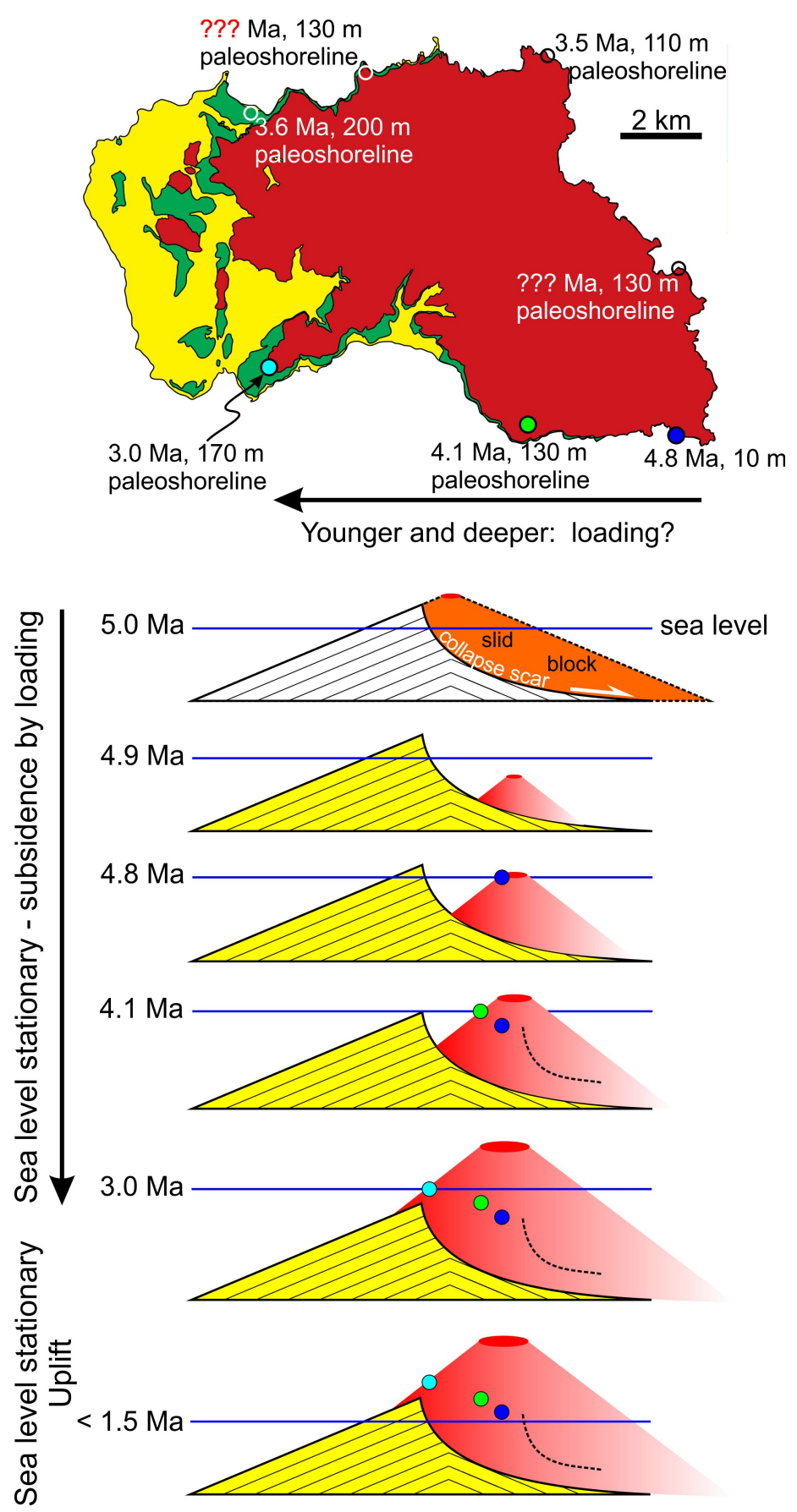

Figure 14. Sketch illustrating subsidence by loading induced by the growing YVC until 2.8 Ma, considering sea level stationary. Note the consistency between growth and subsidence using passage zones along an $E-W$ section on the southern coast (the best constrained). 
shoulder, the flank uplift could still account for the $200 \mathrm{~m}$ of uplift inferred for Santa Maria. If the age inferred for the Terceira Rift is correct (Vogt and Jung, 2004; Marques et al., 2015; Sibrant et al., 2016; Marques et al., 2018), and Santa Maria's upward movement is (at least in part) due to rift flank uplift, then some (or all) of the $200 \mathrm{~m}$ of uplift is younger than ca. $1.5 \mathrm{Ma}$. If we use this age and ca. $200 \mathrm{~m}$ altitude of the highest passage zone to calculate the uplift rate, we calculate a rate of ca. $0.133 \mathrm{~mm} / \mathrm{yr}$, which contrasts with the $0.057 \mathrm{~mm} / \mathrm{yr}$ rate obtained using ca. 3.5 Ma (Ramalho et al., 2017).

\subsection{Marine erosion shelves}

Regarding the evolution of marine shelves, Santa Maria can be used as a reference in the Azores, because: (1) there is no evidence of current appreciable vertical motion; (2) it is similarly affected by the same sea level changes as the younger Azores islands; (3) it is mostly composed of basaltic lava flows and pyroclasts (as in most Azorean islands); (4) it has been volcanically inactive for a long period (>2.8 Ma, Sibrant et al., 2015a); and (5) it is affected by similar weather, wave magnitude and propagation directions to the other Azorean islands. The youngest volcanism in Santa Maria (ca. 3.7 to 2.8 Ma; Sibrant et al., 2015a) occurs as small Strombolian cones scattered on top of the island; therefore, most of the coastal area is made of rocks older than ca. $3 \mathrm{Ma}$, and the western coast is made of rocks older than $5 \mathrm{Ma}$. We look at the first-order topography of the shelves, because we are looking at their relationship with the main evolution of the island (volcanic construction/major landslides). In the absence of volcanic construction in the last $2.8 \mathrm{Ma}$, the explanation for the narrow insular shelves all around Santa Maria, except to the NE, cannot be found in regular marine abrasion and meteoric weathering. We combine the observed short width of the shelf and age of rocks on the coast with the concave shape of the coast and/or shelf edge to propose that the shelf is narrow because of recent medium-scale landsliding. The slide to the south, centred on the village of Praia, could be 


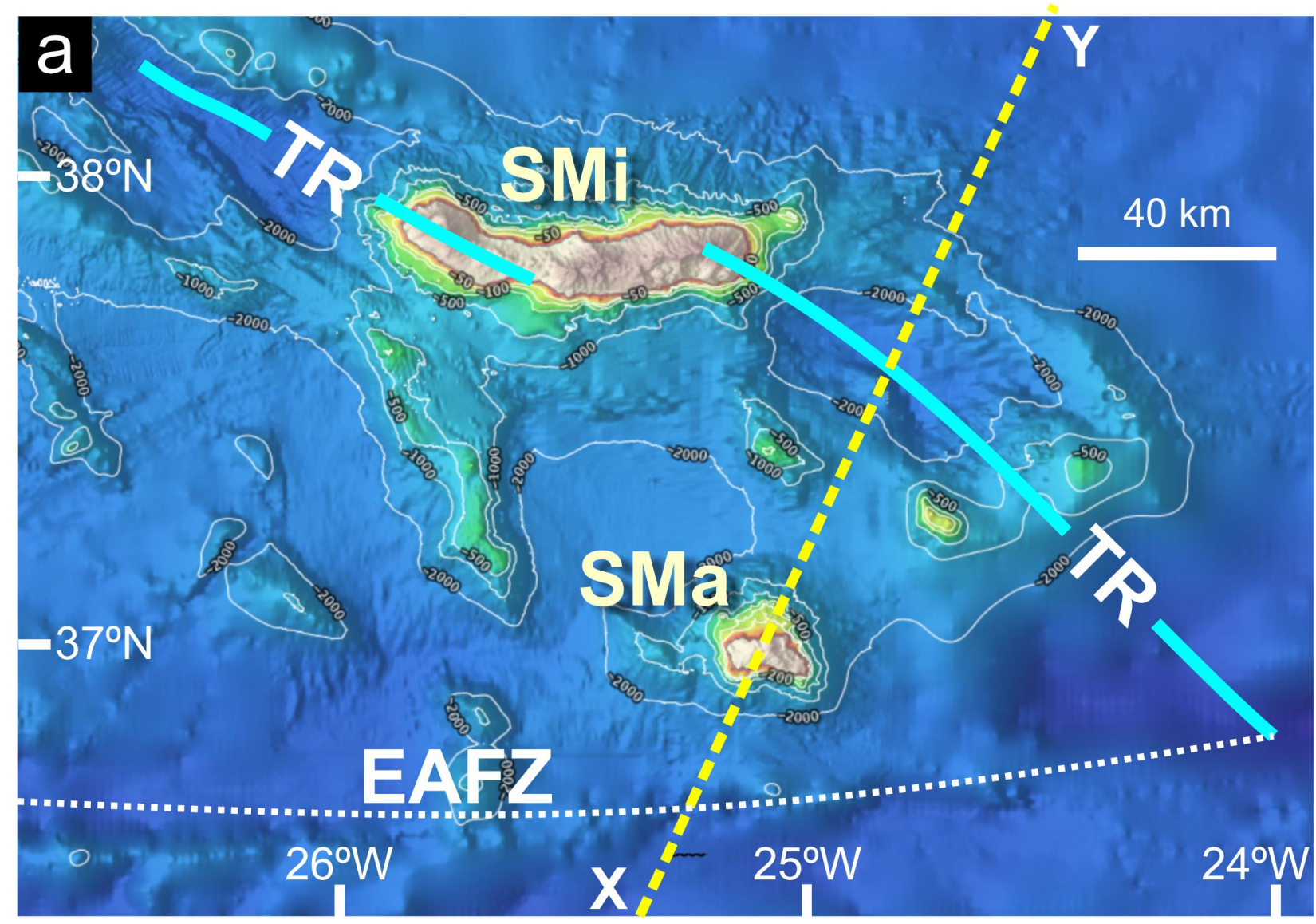

responsible for the development of the large canyon on the headwall, the mouth of which is at

Praia (due to sudden increase in potential energy), and for the slump currently creeping at Praia

(Fig. S-11).

\section{Depth profile}
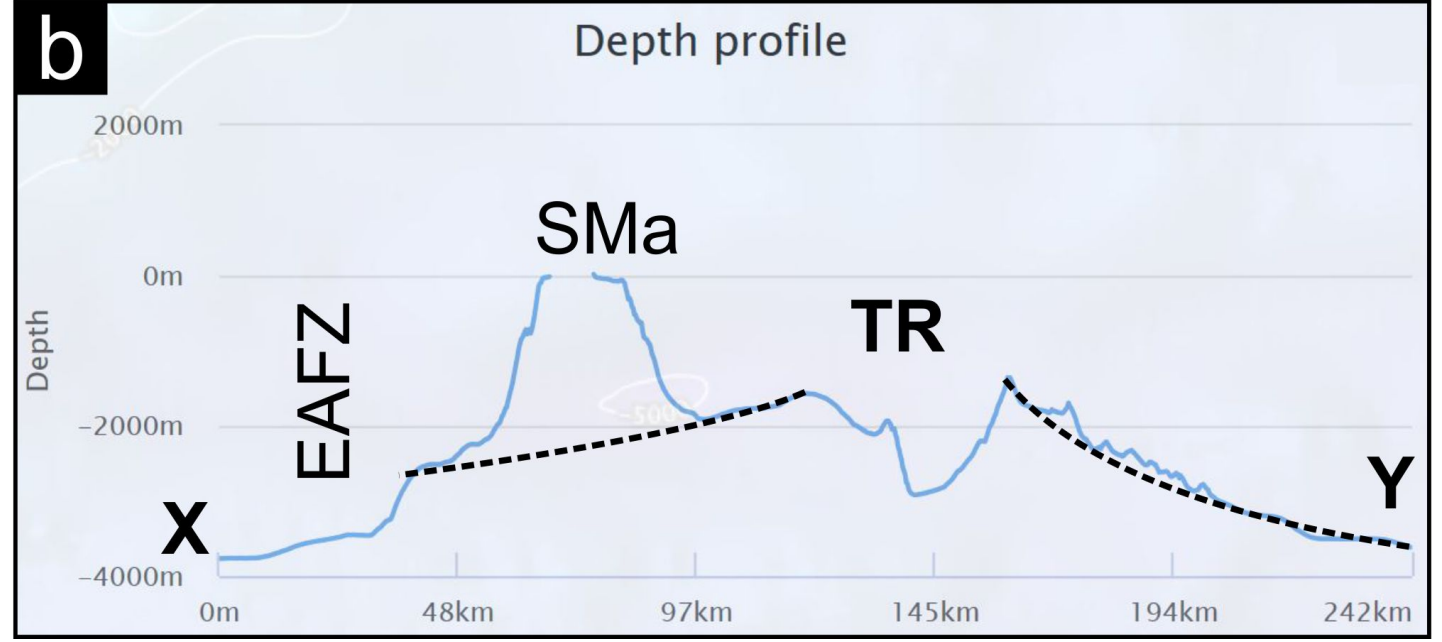

Figure 15. Shaded relief bathymetry around Santa Maria (a), and X-Y topographic profile (b) across the East Azores Fracture Zone (EAFZ), the Santa Maria Island (SMa) and the Terceira Rift (TR). The cross-section shows that Santa Maria sits on the uplifted SSW shoulder of the TR. Background shaded relief from EMODnet portal (https://www.emodnet-bathymetry.eu/). 


\section{Conclusion}

The revised volcanic stratigraphy proposed here for Santa Maria comprises four units, involving three main volcanic complexes (Basement, Old and Young) and a sedimentary complex. The Old and Young volcanic complexes are separated by a major unconformity on which the sedimentary complex lies. The lava flows of the Old and Young volcanic complexes dip gently to the west (consistent with the younging of radiometric ages to the west), and the major unconformity separating them dips gently in the opposite direction, i.e. to the east.

Prior to ca. 6.0 Ma, a seamount (Basement Complex - BC) began growing from the ocean floor to eventually reach the sea surface and form a proto-Santa Maria Island. At around 6.0 Ma, a shield volcano had emerged out of the ocean to form the original Santa Maria Island, which grew until ca. 5.2 Ma, the youngest age of the Old Volcanic Complex.

The time span between the youngest age of the Old Volcanic Complex (ca. 5.3 Ma or younger) and the oldest age of the Young Volcanic Complex (ca. 4.8 Ma or older) is $<0.5 \mathrm{Ma}$, inconsistent with marine and meteoric erosion being responsible for the selective removal of more than half of the first shield volcano. Therefore, we infer that, sometime between 5.2 and 4.9 $\mathrm{Ma}$, a sector collapse removed the whole eastern flank and part of the summit of the first shield volcano (Fig. 14). The east-dipping collapse scar was first covered by a tsunami deposit made of chaotic conglomerates, and later by shallow marine sediments reflecting increasing water depth and age of fossils to the east.

At around 4.9 Ma, the Young Volcanic Complex started filling the collapse scar from east to west (Fig. 14), initially as submarine volcanism. The new shield volcano grew out of the ocean to the east until ca. 3.8 Ma, and the island subsided by more than $100 \mathrm{~m}$ due to loading. Supported by the fact that more than half of the second shield volcano is missing, and that Strombolian cones aged ca. 3.6 Ma lie unconformably on the older Young Volcanic Complex, we infer that a second flank collapse at ca. 3.7 Ma removed the whole eastern flank and the 
summit of the second shield volcano. This second collapse was soon followed by the emplacement of conformable (on the undamaged western flank) and unconformable (on the collapse scar to the east) volcanic cones from ca. 3.6 to $2.8 \mathrm{Ma}$ (Fig. 13). Based on the position of the main feeding centres inferred from the distribution of radial dykes here, we constrain the location of the faults produced by the two inferred flank collapses. Smaller landslides, together with marine and meteoric erosion have further shaped Santa Maria through to its present-day topography, and are responsible for the great variability in marine shelf width around the island. The stress field within the island changed from NNW-SSE to ENE-WSW oriented least compressive stress at around $5 \mathrm{Ma}$, because the orientation of dykes intruding only the Old Volcanic Complex (i.e. older than 5.2 Ma) is mostly WSW-ENE, and dykes intruding only the Young Volcanic Complex (i.e. younger than $4.9 \mathrm{Ma}$ ) are mostly oriented NNW-SSE.

Coincidently, the inferred collapse faults have an orientation similar to the normal faults mapped at Santa Maria, which suggests a genetic relationship between extension/rifting and large-scale mass wasting on the island.

From the current altitude occupied by sub-aerial and submarine lavas, we can conclude that Santa Maria has undergone important vertical movements throughout its evolution.

Subsidence occurred during growth of the YVC, as attested by the diachronic deposition of marine sediments (which are younger to the west) and the distribution of marine and sub-aerial lavas of the YVC. Given that uplift postdates submarine volcanism (youngest at ca. 3.0 Ma), magma ponding as a mechanism to explain the inferred uplift is not consistent with the current data on Santa Maria. Instead, the major uplift experienced by Santa Maria, as indicated by submarine lavas outcropping at ca. $200 \mathrm{~m}$ asl, is here considered as being the result of rift flank uplift on the southern shoulder of the nearby Terceira Rift in the last ca. 1.5 Ma.

We conclude that one can identify large-scale sector collapses based on data collected onshore, mostly through the recognition of major unconformities and their interpretation, i.e. that 
they represent the removal of large portions (more than half) of the earlier edifice. Here we show that the inferred flank collapses may have been triggered by tectonic stresses and strain, i.e. during a rifting stage active at around 5-3 Ma that produced the Santa Maria transient rift. Therefore, Santa Maria can be used as a case-study for similar oceanic islands in tectonically active settings.

\section{Acknowledgments}

This is a contribution to Project MEGAHazards2 (PTDC/GEO-GEO/0946/2014) funded by FCT Portugal. A. Costa benefitted from a scholarship (SFRH/BD/68983/2010) funded by FCT Portugal, and A.L.R. Sibrant was supported by postdoctoral grant of the "Laboratoire d'Excellence" LabexMER. A special thanks is due to João Batista, who took us by boat all around the island to carry out critical field work. We thank three anonymous Reviewers and the Executive and Associate Editors Andrew Harris and Valerio Acocella, respectively, for their constructive and helpful reviews, and editorial work.

\section{References}

Abdel-Monem, A.A., Fernandez, L.A., Boone, G.M., 1975. K-Ar ages from the eastern Azores group (Santa Maria, São Miguel and the Formigas Islands). Lithos 8, 247-254.

Agostinho, J., 1937. Sobre a tectónica da ilha de Santa Maria. Açoreana 1, 281-285.

Ávila, S.P., Ramalho, R.S., Habermann, J.M., Titschack, J., 2018. The Marine Fossil Record at Santa Maria Island (Azores). In Volcanoes of the Azores, Active Volcanoes of the World, U. Kueppers and C. Beier (eds.), https://doi.org/10.1007/978-3-642-32226-6_9. Springer-Verlag GmbH Germany, part of Springer Nature 2018.

Beier, C., Mata, J., Stöckhert, F., Mattielli, N., Brandl, P.A., Madureira, P., Genske, F.S., Martins, S., Madeira, J., Haase, K.M., 2013. Geochemical evidence for melting of carbonated 
peridotite on Santa Maria Island, Azores. Contrib Mineral Petrol 165, 823-841. https://doi.org/10.1007/s00410-012-0837-2

Boulesteix, T., Hildenbrand, A., Soler, V., Gillot, P.Y., 2012. Eruptive response of oceanic islands to giant landslides: new insights from the geomorphologic evolution of the Teide-Pico Viejo volcanic complex (Tenerife, Canary). Geomorphology 138, 61-73.

Boulesteix, T., Hildenbrand, A., Soler, V., Quidelleur, X., Gillot, P.Y., 2013. Coeval giant landslides in the Canary Islands: implications for global, regional and local triggers of giant flank collapses on oceanic volcanoes. J. Volcanol. Geotherm. Res. 257, 90-98.

Cas, R.A.F., Wright, J.V., 1987. Volcanic successions, modern and ancient: London-New YorkTokyo-Melbourne-Madras, Chapman \& Hall, 528 p.

Casalbore, D., Romagnoli, C., Pimentel, A., Quartau, R., Casas, D., Ercilla, G., Hipólito, A., Sposato, A., Chiocci, F. L., 2015. Volcanic, tectonic and mass-wasting processes offshore Terceira Island (Azores) revealed by high-resolution seafloor mapping. Bull. Volc. 77: 24. Doi: 10.1007/s00445-015-0905-3.

Costa, A.C.G., Hildenbrand, A., Marques, F.O., Sibrant, A.L.R., Santos de Campos, A., 2015. Catastrophic flank collapses and slumping in Pico Island during the last $130 \mathrm{kyr}$ (Pico-Faial ridge, Azores Triple Junction). Journal of Volcanology and Geothermal Research 302, 33-46.

Costa, A.C.G., Marques, F.O., Hildenbrand, A., Sibrant, A.L.R., Catita, C.M.S., 2014. Largescale flank collapses in a steep volcanic ridge: Pico-Faial Ridge, Azores Triple Junction. Journal of Volcanology and Geothermal Research 272, 111-125.

DeMets, C., Gordon, R.G., Argus, D.F., 2010. Geologically current plate motions. Geophys. J. Int. $181,1-80$.

EMODnet Bathymetry Consortium (2018). EMODnet Digital Bathymetry (DTM 2018). https://doi.org/10.12770/18ff0d48-b203-4a65-94a9-5fd8b0ec35f6.

Germa, A., Quidelleur, X., Gillot, PY., Tchilinguirian, P., 2010. Volcanic evolution of the back- 
arc Pleistocene Payun Matru volcanic field (Argentina). Journal of South American Earth Sciences 29, 717-730.

Germa, A., Quidelleur, X., Lahitte, P., Labanieh, S., Chauvel, C., 2011. The K-Ar CassignolGillot technique applied to western Martinique lavas: A record of Lesser Antilles arc activity from 2 Ma to Mount Pelée volcanism. Quaternary Geochronology 6, 341-355.

Gillot, P.Y., Cornette, Y., 1986. The Cassignol technique for potassium-argon dating, precision and accuracy: examples from late Pleistocene to recent volcanics from southern Italy. Chemical Geology 59, 205-222.

Gillot, P.Y., Cornette, Y., Max, N., Floris, B., 1992. Two reference materials, trachytes MDO-G and ISH-G, for argon dating K/Ar and 40Ar/39Ar dating of Pleistocene and Holocene rocks. Geostandards and Geoanalytical Research 16, 55-60.

Gillot, P.Y., Hildenbrand, A., Lefèvre, J.C., Albore-Livadie, C., 2006. The K-Ar dating method: Principle, Analytical Techniques and Application to Holocene Volcanic Eruptions in the southern Italy. Acta Vulcanologica 18, 55-66.

Gillot, P.Y., Lefèvre, J.C., Nativel, P.E., 1994. Model for the structural evolution of the volcanoes of Réunion Island. Earth Planet. Sci. Lett. 122, 291-302.

Hildenbrand, A., Gillot, P.Y., Bonneville, A., 2006. Off-shore evidence for a huge landslide of the northern flank of Tahiti-Nui (French Polynesia). Geochemistry Geophysics Geosystems 7, $1-12$

Hildenbrand, A., Gillot, P.Y., Le Roy, I., 2004. Volcano-tectonic and geochemical evolution of an oceanic intra-plate volcano: Tahiti-Nui (French Polynesia). Earth Planet. Sci. Lett. 217, 349-365.

Hildenbrand, A., Gillot, P.Y., Marlin, C., 2008. Geomorphological study of long-term erosion on a tropical volcanic ocean island: Tahiti-Nui (French Polynesia). Geomorphology 93, 460-481. Hildenbrand, A., Madureira, P., Marques, F.O., Cruz, I., Henry, B., Silva, P., 2008. Multi-stage 
evolution of a sub-aerial volcanic ridge over the last 1.3 Myr: S. Jorge Island, Azores Triple Junction. Earth and Planetary Science Letters 273, 289-298.

Hildenbrand, A., Marques, F.O., Catalão, J., 2018. Large-scale mass wasting on small volcanic islands revealed by the study of Flores Island (Azores). Nature Scientific Reports 8, 13898; DOI:10.1038/s41598-018-32253-0

Hildenbrand, A., Marques, F.O., Catalão, J., Catita, C.M.S., Costa, A.C.G., 2012a. Large-scale active slump of the southeastern flank of Pico Island, Azores. Geology 40, 939-942.

Hildenbrand, A., Marques, F.O., Costa, A.C.G., Sibrant, A.L.R., Silva, P.F., Henry, B., Miranda, J.M., Madureira, P., 2012b. Reconstructing the architectural evolution of volcanic islands from combined $\mathrm{K} / \mathrm{Ar}$, morphologic, tectonic, and magnetic data: the Faial Island example (Azores). Journal of Volcanology and Geothermal Research 241-242, 39-48.

Jones, J.G., 1969. Pillow lavas as depth indicators. American Journal of Science 267, 181-195. Jones, J., Nelson, P., 1970. The flow of basalt lava from air into water, its structural expression and stratigraphic significance. Geological Magazine 107, 13-19.

Luís, J.F., Miranda, J.M., Galdeano, A., Patriat, P., Rossignol, J.C., Mendes Victor, L.A., 1994. The Azores triple junction evolution since $10 \mathrm{Ma}$ from an aeromagnetic survey of the MidAtlantic Ridge. Earth Planet. Sci. Lett. 125, 439-459.

Madeira, P., Kroh, A., Martins, A. M. F., Ávila, S.P., 2007. The marine fossils from Santa Maria Island (Azores, Portugal): an historical overview. In S.P. Ávila \& A.M.F. Martins (Eds.), Proceedings of the "1st Atlantic Islands Neogene", International Congress, Ponta Delgada, 12-14 June 2006. Açoreana, Suplemento 5, 59-73.

Marques, F.O., Catalão, J.C., DeMets, C., Costa, A.C.G., Hildenbrand, A., 2013a. GPS and tectonic evidence for a diffuse plate boundary at the Azores Triple Junction. Earth and Planetary Science Letters 381, 177-187.

Marques, F.O., Catalão, J.C., DeMets, C., Costa, A.C.G., Hildenbrand, A., 2014a. Corrigendum 
to "GPS and tectonic evidence for a diffuse plate boundary at the Azores Triple Junction" [Earth Planet. Sci. Lett. 381 (2013) 177-187]. Earth Planet. Sci. Lett. 387, 1-3.

Marques, F.O., Catalão, J., Hildenbrand, A., Costa, A.C.G., Dias, N.A., 2014b. The 1998 Faial earthquake, Azores: Evidence for a transform fault associated with the Nubia-Eurasia plate boundary? Tectonophysics $633,115-125$.

Marques, F.O., Catalão, J., Hildenbrand, A., Madureira, P., 2015. Ground motion and tectonics in the Terceira Island: tectonomagmatic interactions in an oceanic rift (Terceira Rift, Azores Triple Junction). Tectonophysics 651-652, 19-34.

Marques, F.O., Cobbold, P.R., 2002. Topography as a major factor in the development of arcuate thrust belts: Insights from sandbox experiments. Tectonophysics 348, 247-268.

Marques, F.O., Hildenbrand, A., Hübscher, C., 2018. Evolution of a volcanic island on the shoulder of an oceanic rift and geodynamic implications: S. Jorge Island on the Terceira Rift, Azores Triple Junction. Tectonophysics 738-739, 41-50.

Marques, F.O., Hildenbrand, A., Victória, S.S., Cunha, C., Dias, P., 2019. Caldera or flank collapse in the Fogo volcano? What age? Consequences for risk assessment in volcanic islands. Journal of Volcanology and Geothermal Research 388, 106686 https://doi.org/10.1016/j.jvolgeores.2019.106686

Marques, F.O., Hildenbrand, A., Zanon, V., Boulesteix, T., 2016. Comment on "The insular shelves of the Faial-Pico Ridge (Azores archipelago): a morphological record of its evolution" by Quartau et al. (2015). Geochemistry, Geophysics, Geosystems 17, 625-632.

Marques, F. O., Hildenbrand, A., Zeyen, H., Cunha, C., Victória, S.S., 2020. The complex vertical motion of intraplate oceanic islands assessed in Santiago Island, Cape Verde. Geochem., Geophys., Geosyst., 21, e2019GC008754. https://doi.org/10.1029/2019GC008754 Marques, F.O., Sibrant, A.L.R., Hildenbrand, A., Costa, A.C.G., 2013b. Large-scale sector collapses in the evolution of Santa Maria Island, Azores. Abstract V51D-2719, AGU Fall 
Meeting.

Miller, K., Kominz, M., Browning, J., Wright, J., Mountain, G., Katz, M., Sugarman, P., Cramer, B., Christie-Blick, N., and Pekar, S., 2005. The Phanerozoic record of global sea-level change. Science 310, 1293-1298.

Miranda, J.M., J.F. Luis, N. Lourenço, J. Goslin, 2014. Distributed deformation close to the Azores Triple "Point". Mar. Geol. 355, 27-35.

Mitchell, N.C., 2003. Susceptibility of mid-ocean ridge volcanic islands and seamounts to largescale landsliding. J. Geophys. Res. 108, 2397. http://dx.doi.org/10.1029/2002JB001997.

Porebski, S., Gradzinski, R., 1990. Lava-fed Gilbert-type delta in the Polonez Cove Formation (Lower Oligocene), King George Island, West Antarctica. In A. Colella, \& D. Prior (Eds.), Coarse Grained Deltas (vol. 10). International Association of Sedimentologists Special Publication, pp. 335-351.

Quartau, R., Hipólito, A., Romagnoli, C., Casalbore, D., Madeira, J., Tempera, F., Roque, C., Chiocci, F.L., 2014. The morphology of insular shelves as a key for understanding the geological evolution of volcanic islands: insights from Terceira Island (Azores). Geochem. Geophys. Geosyst. 15, 1801-1826.

Quartau, R., Madeira, J., Mitchell, N.C., Tempera, F., Silva, P.F., Brandão, F., 2015. The insular shelves of the Faial-Pico Ridge: A morphological record of its geologic evolution (Azores archipelago). Geochemistry Geophysics Geosystems 16, 1401-1420.

Quartau, R., Tempera, F., Mitchell, N.C., Pinheiro, L.M., Duarte, H., Brito, P.O., Bates, R., Monteiro, J.H., 2012. Morphology of the Faial Island shelf (Azores): the interplay between volcanic, erosional, depositional, tectonic and mass-wasting processes. Geochem. Geophys. Geosyst. 13, Q04012. Doi: 10.1029/2011GC003987.

Quidelleur, X., Hildenbrand, A., Samper, A., 2008. Causal link between Quaternary paleoclimatic changes and volcanic islands evolution. Geophys. Res. Lett. 35, L02303, 
doi:10.1029/2007GL031849.

Ramalho, R.S., Helffrich, G., Cosca, M., Vance, D., Hoffmann, D., Schmidt, D.N., 2010a. Vertical movements of ocean island volcanoes: Insights from a stationary plate environment. Mar. Geol. 275, 84-95.

Ramalho, R., Helffrich, G., Cosca, M, Vance, D., Hoffmann, D., Schmidt, D.N., 2010b. Episodic swell growth inferred from variable uplift of the Cape Verde hotspot islands. Nat. Geosc. 3, 774-777.

Ramalho, R., Helffrich, G., Schmidt, D. N. \& Vance, D., 2010c. Tracers of uplift and subsidence in the Cape Verde Archipelago. J. Geol. Soc. Lond. 167, 519-538.

Ramalho, R. S., Quartau, R., Trenhaile, A. S., Mitchell, N. C., Woodroffe, C. D., Avila, S. P., 2013. Coastal evolution on volcanic oceanic islands: a complex interplay between volcanism, erosion, sedimentation, sealevel change and biogenic production. Earth-Science Reviews, 127 $140-170$.

Ramalho, R.S., Helffrich, G., Madeira, J., Cosca, M., Thomas, C., Quartau, R., Hipólito, A., Rovere, A., Hearty, P.J., Ávila, S.P., 2017. Emergence and evolution of Santa Maria Island (Azores): The conundrum of uplifted islands revisited. Geological Society of America Bulletin, 129, 372-390.

Ricchi, A., Quartau, R., Ramalho, R.S., Romagnoli, C., Casalbore, D., Cruz, J.V., Fradique, C., Vinhas, A., 2018. Marine terrace development on reefless volcanic islands: New insights from high-resolution marine geophysical data offshore Santa Maria Island (Azores Archipelago). Marine Geology 406, 42-56.

Ricci, J., Quidelleur, X., Lahitte, P., 2015. Volcanic evolution of central Basse-Terre Island revisited on the basis of new geochronology and geomorphology data. Bull. Volcanol. 77, 84. Doi: 10.1007/s00445-015-0970-7.

Ricci, J., Quidelleur, X., Pallares, C., Lahitte, P., 2017. High-resolution K-Ar dating of a 
complex magmatic system: the example of Basse-Terre Island (French West Indies). J. Volcanol. Geotherm. Res. 345, 142-160.

Serralheiro, A., 2003. A Geologia da ilha de Santa Maria, Açores. Açoreana 10, 141-192.

Serralheiro, A., Alves, C.A.M., Forjaz, V.H., Rodrigues, B., 1987. Carta vulcanológica dos Açores: ilha de Santa Maria. Edição do Serv. Reg. Protecção Civil (Região Autónoma dos Açores), Ponta Delgada, $1^{a}$ ed., 2 folhas.

Serralheiro, A., Madeira, J., 1993. Stratigraphy and geochronology of Santa Maria Island (Azores). Açoreana 7, 575-592.

Sibrant, A.L.R., Marques, F.O., Hildenbrand, A., 2014. Construction and destruction of a volcanic island developed inside an oceanic rift: Graciosa Island, Terceira Rift, Azores. Journal of Volcanology and Geothermal Research 284, 32-45.

Sibrant, A.L.R., Hildenbrand, A., Marques, F.O., Costa, A.C.G., 2015a. Volcano-tectonic evolution of the Santa Maria Island (Azores): implications for palaeostress evolution at the western Eurasia-Nubia plate boundary. Journal of Volcanology and Geothermal Research 291, 49-62.

Sibrant, A.L.R., Hildenbrand, A., Marques, F.O., Weiß, B., Boulesteix, T., Hübscher, C.. Lüdmann, T., Costa, A.C.G., Catalão, J.C., 2015b. Morpho-structural evolution of a volcanic island developed inside an active oceanic rift: S. Miguel Island (Terceira Rift, Azores). Journal of Volcanology and Geothermal Research 301, 90-106.

Sibrant, A.L.R., Marques, F.O., Hildenbrand, A., Boulesteix, T., Costa, A.C.G., Catalão, J., 2016. Deformation in a hyperslow oceanic rift: Insights from the tectonics of the São Miguel Island (Terceira Rift, Azores). Tectonics 35, 425-446.

Steiger, R.H., Jager, E., 1977. Subcommission on geochronology: convention on the use of decay constants in geo and cosmochronology. Earth Planet. Sci. Lett. 36, 359-362.

Trippanera, D., Porreca, M., Ruch, J., Pimentel, A., Acocella, V., Pacheco, J., Salvatore, M., 
2014. Relationships between tectonics and magmatism in a transtensive/transform setting: An example from Faial Island (Azores, Portugal). GSA Bulletin 126, 164-181. Doi: $10.1130 / \mathrm{B} 30758.1$ scale 1:50 000. Serviço Geológico de Portugal.

Turcotte, D.L., Schubert, G., 2014. Geodynamics. Cambridge University Press, $3^{\text {rd }}$ Edition, 636 pp.

Vogt, P., Jung, W., 2004. The Terceira Rift as hyper-slow, hotspot-dominated oblique spreading axis: A comparison with other slow-spreading plate boundaries: Earth and Planetary Science Letters 218, 77-90.

Weiß, B.J., Hübscher, C., Lüdmann, T., Serra, N., 2016. Submarine sedimentation processes in the southeastern Terceira Rift/São Miguel region (Azores). Marine Geology 374, 42-58.

Weissel, J.K., Karner, G.D., 1989. Flexural uplift of rift flanks due to mechanical unloading of the lithosphere during extension. J. Geophys. Res. 94, 13919-13950.

Wilson, S.A., 1997. The collection, preparation and testing of USGS reference material BCR-2, Columbia River Basalt. USGS, Denver.

Zbyszewski, G., Ferreira, O.V., 1960. Carta geológica de Portugal, Ilha de Santa Maria (Açores), 


\section{Supplementary material}

\section{Appendix $1-K$-Ar dating method}

Careful microscopic examination of thin-sections was carried out to identify the textural and petrographic characteristics of the samples and ensure that they did not suffer any significant alteration. As all our new samples from Santa Maria are basic to slightly evolved lavas, the groundmass was selected. The samples were crushed and sieved to the chosen fraction (typically 125-250 $\mu \mathrm{m}$, except sample SMa16O sieved at 125-250 $\mu \mathrm{m})$. After ultrasonic cleaning in a dilute nitric acid solution (10\%), followed by complete rinsing in distilled water and drying, heavy liquids were used to eliminate all the phenocrysts (e.g., plagioclase, pyroxene or olivine phenocrysts), which are K-poor and may carry potentially unsuitable inherited excess ${ }^{40} \mathrm{Ar}$. The samples were then dated with the K-Ar Cassignol-Gillot technique, which has been shown wellsuited to date Quaternary volcanic products precisely, even low-K basalts and andesites (Gillot et al., 2006; Quidelleur et al., 2008; Germa et al., 2010, 2011; Boulesteix et al., 2012; 2013; Ricci et al., 2015; 2017). This technique has been extensively used in the last decade to constrain the age of volcanism and flank instabilities in the Azores (Hildenbrand et al., 2008; 2012a,b, 2012; Costa et al., 2014; 2015; Sibrant et al., 2014, 2015a,b, 2016). K was measured by flame absorption spectrometry and compared with standards MDO-G (Gillot et al., 1992) and BCR-2 (Wilson, 1997), both attacked and measured in the same conditions as the samples. Ar was measured by sector mass spectrometry (Gillot and Cornette, 1986). Details about the analytical procedure and calculation of uncertainties can be found elsewhere (e.g. Gillot et al., 2006; Germa et al., 2010; Boulesteix et al., 2013; Hildenbrand et al., 2014; 2018). Decay constants and isotopic ratios of Steiger and Jäger (1977) were used. 


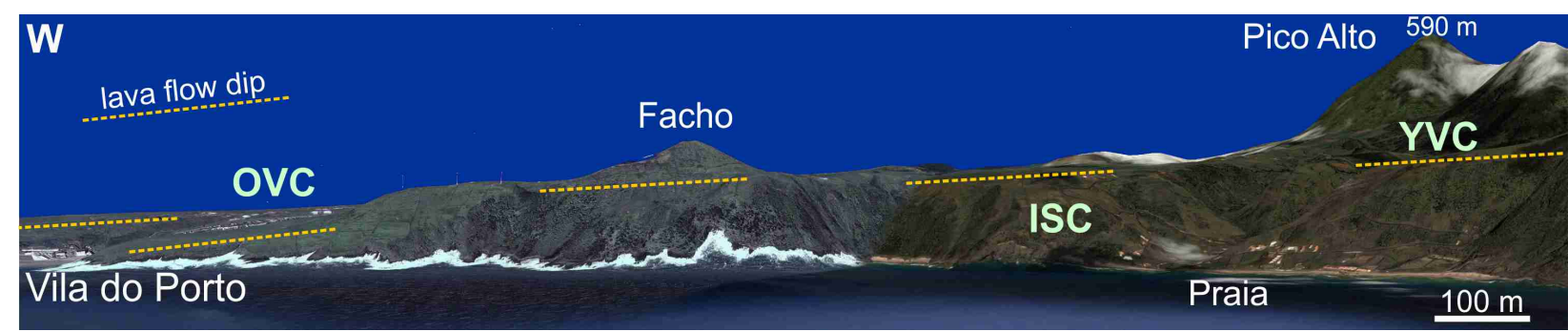

Figure S-1. 3-D Google Earth image to show that the gentle slope to the west is mainly structural, i.e. closely follows lava flow dip (dashed orange lines). The steps observed on the topography can therefore represent the front of successive lava flows that did not reach the same distance from the feeder. OVC, ISC and YVC stand for Old Volcanic Complex, Intermediate Sedimentary Complex, and Young Volcanic Complex, respectively. Data from SIO, NOAA, U.S. Navy, NGA, GEBCO.

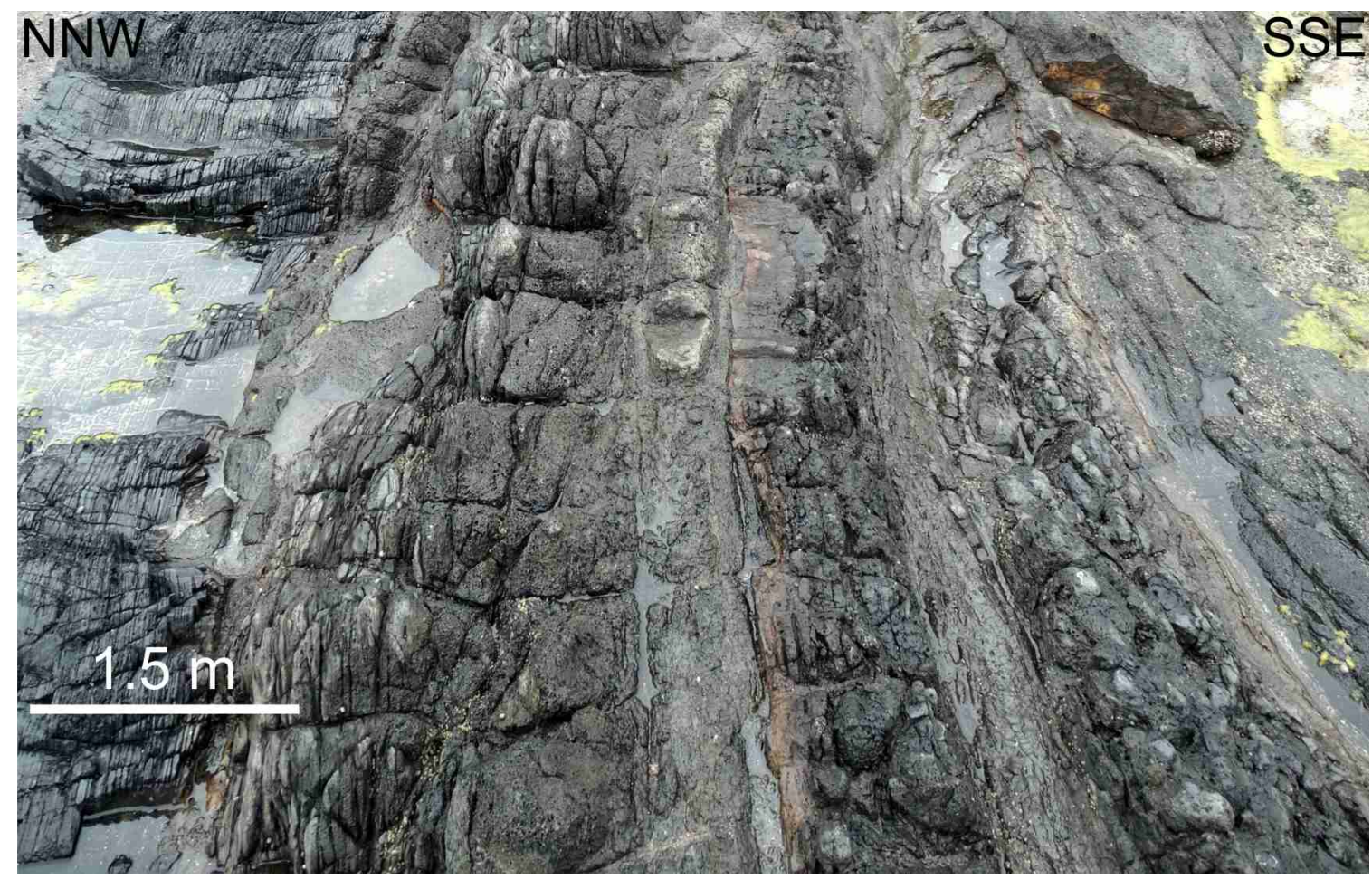

Figure S-2. Multiple injection, sub-vertical dyke striking ENE-WSW, indicating preferential NNW-SSE opening. 


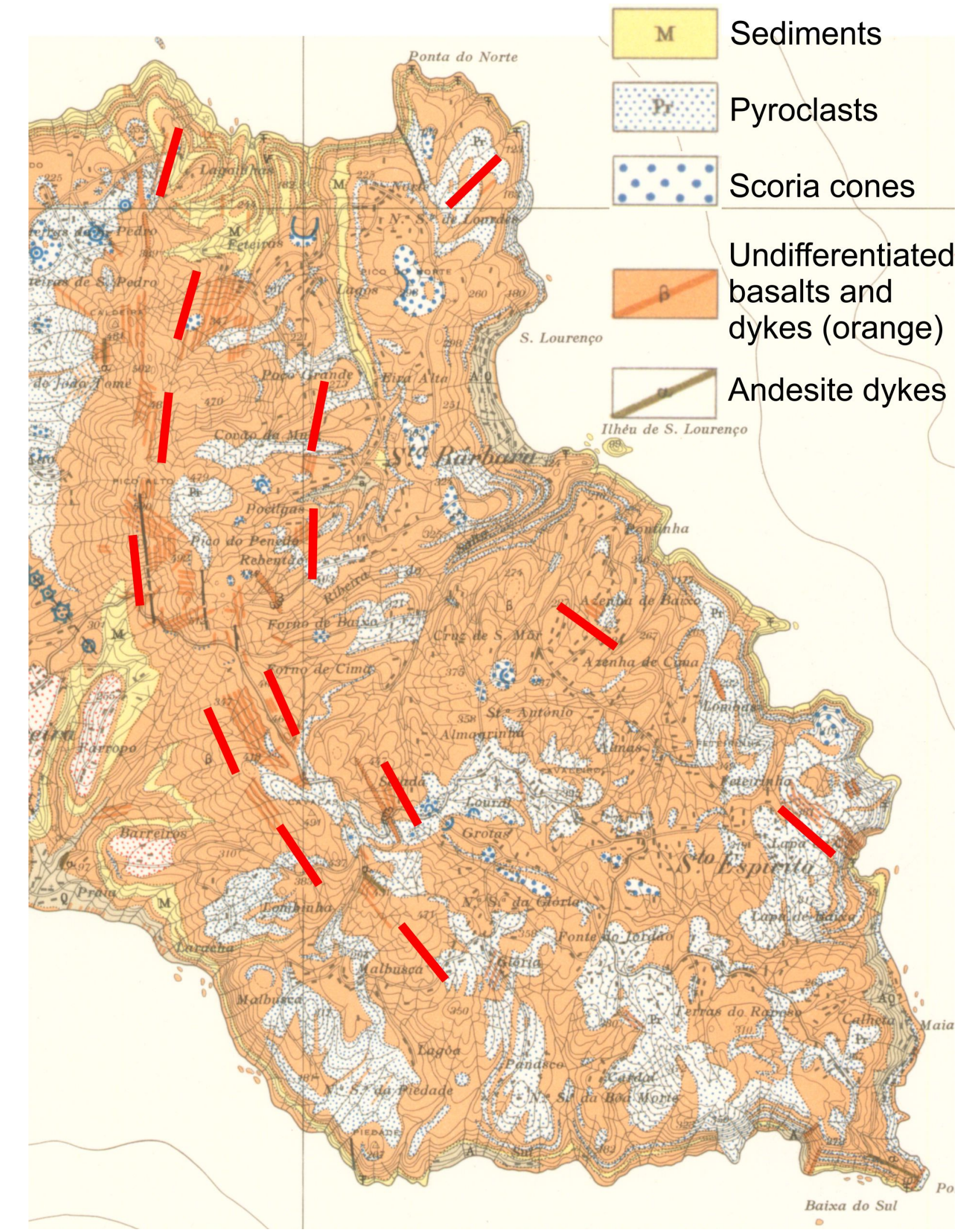

Fig. S-3. Extract of the geological map of Zbyszewski and Ferreira (1960) in which dykes (orange lines) display a curved, concave to east, trend (highlighted in red), varying from $N W$ $S E$ in the south, to NNE-SSW in the north. 


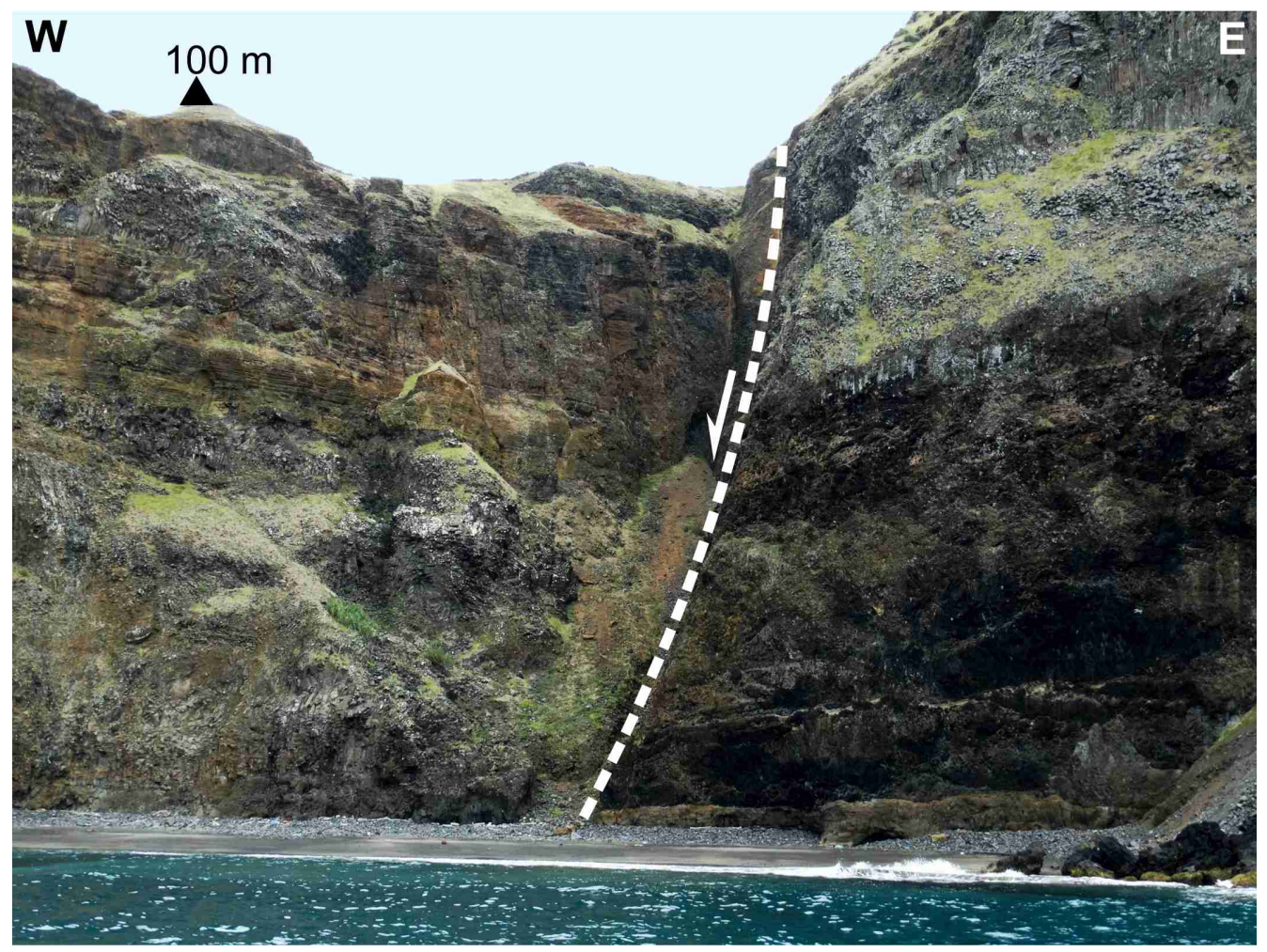

Figure S-4. Normal fault dipping to the west. This normal faulting attests to the change in the stress field from NNW-SSE $\sigma_{3}$ (dominant dykes of the OVC) to ENE-WSW $\sigma_{3}$ (dominant normal faulting cutting $O V C$ and $Y V C$ ). 


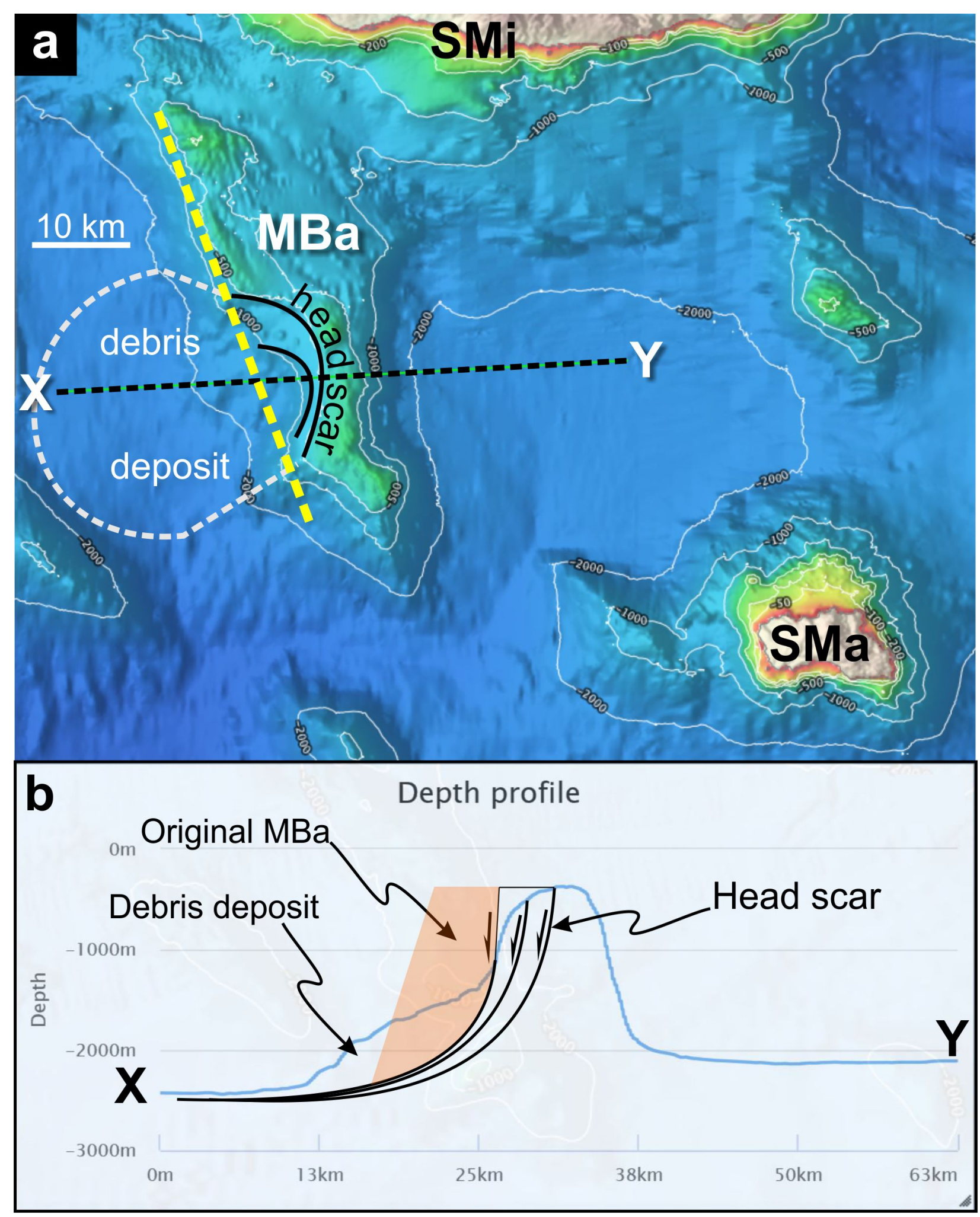

Figure S-5. (a) - Shaded relief of the bathymetry around the Monaco Bank (MBa) and Santa Maria Island (SMa). The flat and elongated top of the MBa is interrupted by a half-moon scar concave to the west, which, similarly to Weiß et al. (2016), we interpret as the scar of a LSMW, the debris deposit of which is visible in the bathymetric profile shown in (b). Note that the full Santa Maria Island fits inside the scar, which gives an idea of the dimension of the MBa LSMW.

The yellow dashed line marks the original position of the western edge of the MBa. The X-Y dashed line marks the location of the bathymetric profile shown in (b). Background shaded relief 
1005

1006

1007

1008

1009 from EMODnet portal (https://www.emodnet-bathymetry.eu/). (b) - Bathymetric profile with interpreted landslide faults, mainly based on the scars observed on the bathymetry. Light orange shaded wedge represents the original shape of the MBa in an E-W section, which compares very well with the inferred debris deposit. The orange shaded wedge was drawn using the distance from the original MBa western edge to the head scar, and the MBa eastern slope. 


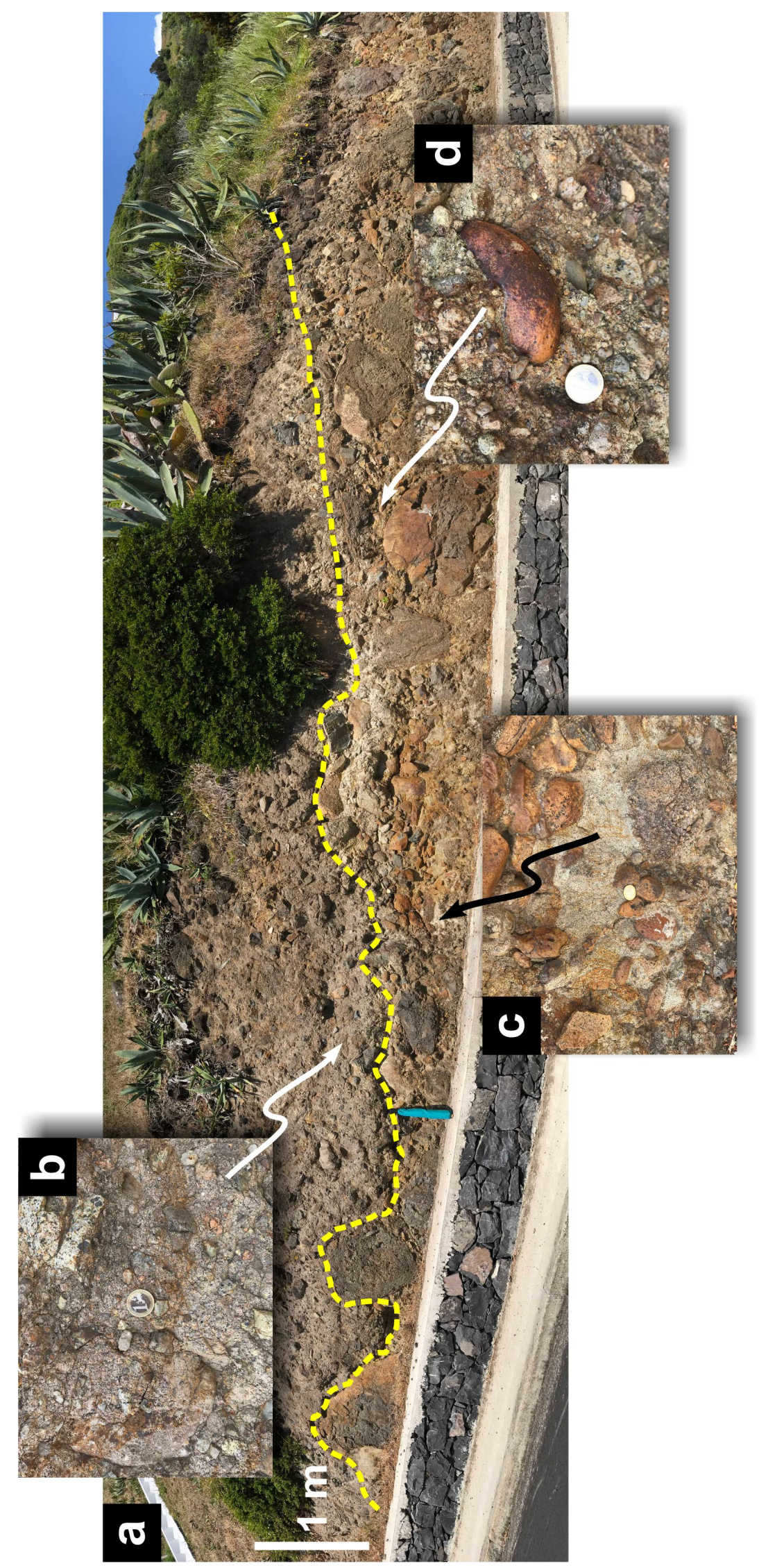

1011 Figure S-6. Image of the polygenetic chaotic debris deposit outcropping on the road going down to Praia. Insets to show details described in the text. Green umbrella (ca. $0.5 \mathrm{~m}$ long) for scale in 


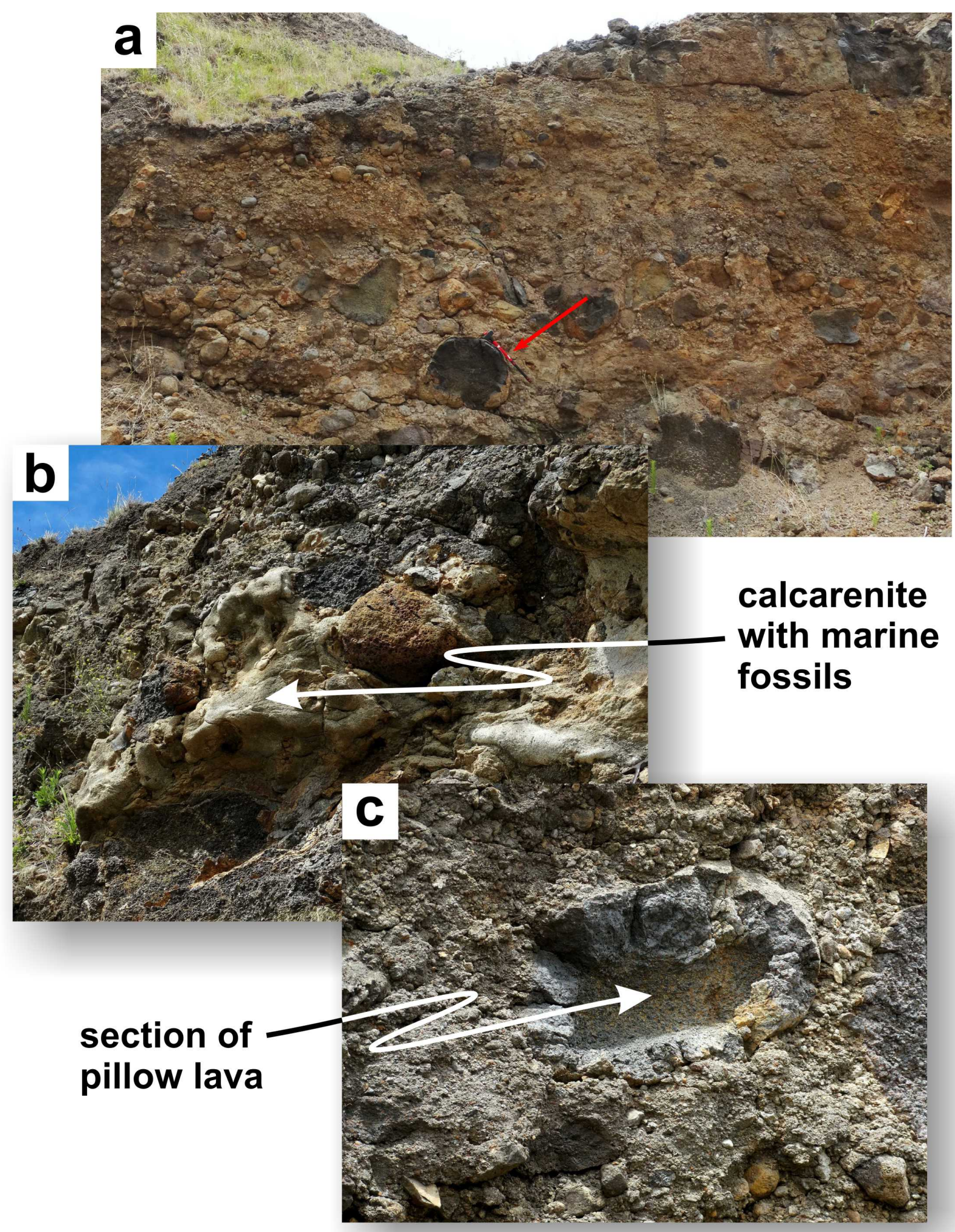

Figure S-7. Image of chaotic debris deposit (a) containing large boulders originated in the sea: calcarenite with many marine fossils (b) and section of submarine pillow lava (c). The debris deposit lies unconformably on sub-aerial Old Volcanic Complex. Red arrow points to sledgehammer (ca. $1 \mathrm{~m}$ long handle) on pillow lava for scale. 


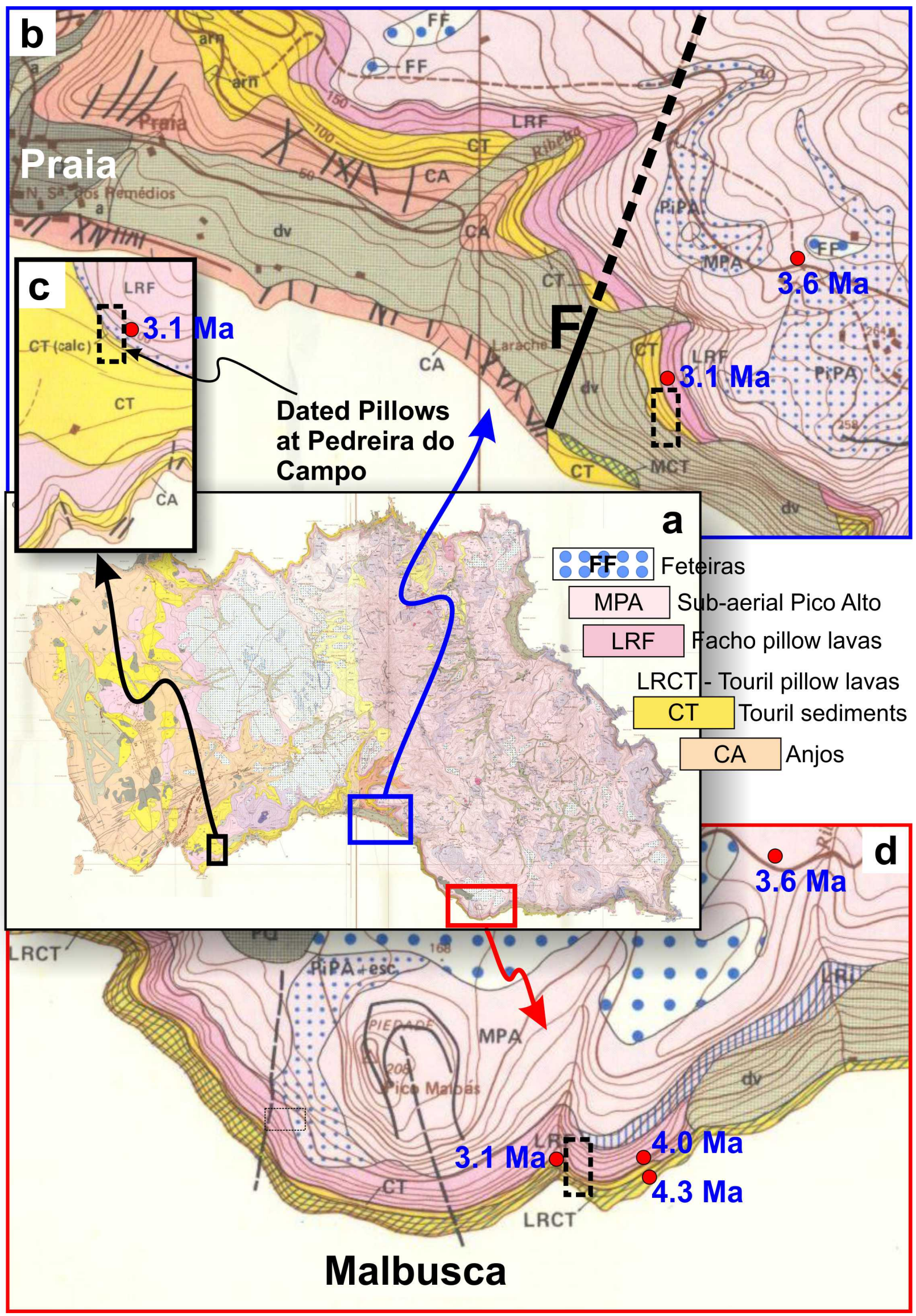


three extracts of the map to show inconsistencies between the stratigraphy established in 1987 and the stratigraphy constrained here and in Sibrant et al. (2015a) by K-Ar dating. Note that: (1) extrapolation of the age of dated pillows at Pedreira do Campo (c) to similar settings ( $b$ and d) along the same yellow unit to the east (CT, Complexo do Touril of Serralheiro et al., 1987) leads to major inconsistencies; (2) the submarine lavas (LRF) here dated at 3.1 Ma at Pedreira do Campo (c) cannot be overlain by lava flows that are older ( $b$ and $d$ ); (3) the CT sediments at Pedreira do Campo (ca. $3.2 \mathrm{Ma}$ ) cannot be the same as the CT sediments to the east atop Praia (b) and at Malbusca (ca. 4.1 Ma) in (d); (4) there must be a scarp where a thick black line is drawn in (b) and marked $F$, because the CA unit ends abruptly at sea level, it reaches $150 \mathrm{~m}$ altitude immediately to the north, and the chaotic debris deposit (CT) also ends here, where the conglomeratic deposit passes into submarine lavas of the LRCT; this scarp/fault has to be older than the CT because it does not cut it.

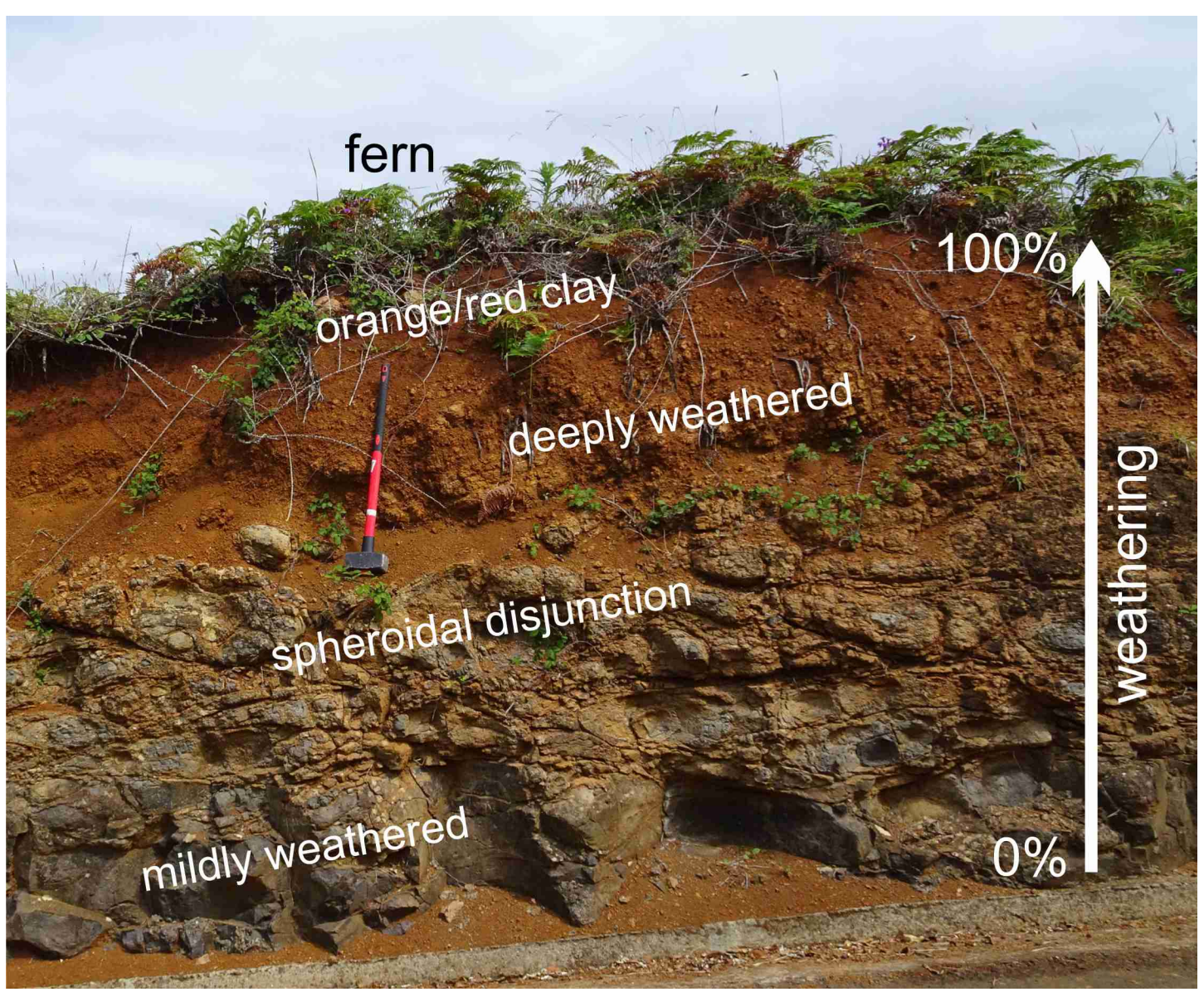

Figure S-9. Typical outcrop of the "Feteiras Formation". It is clear from this image that the top orange clay is not a pyroclast, it is the product of deep weathering of a lava flow from the YVC. This is a typical outcrop that can be found in tropical islands like Oahu, in Hawaii (cf. Google image, red soil visible on the NW quadrant of Oahu where the Portuguese settlers grew sugar cane and pineapple). 


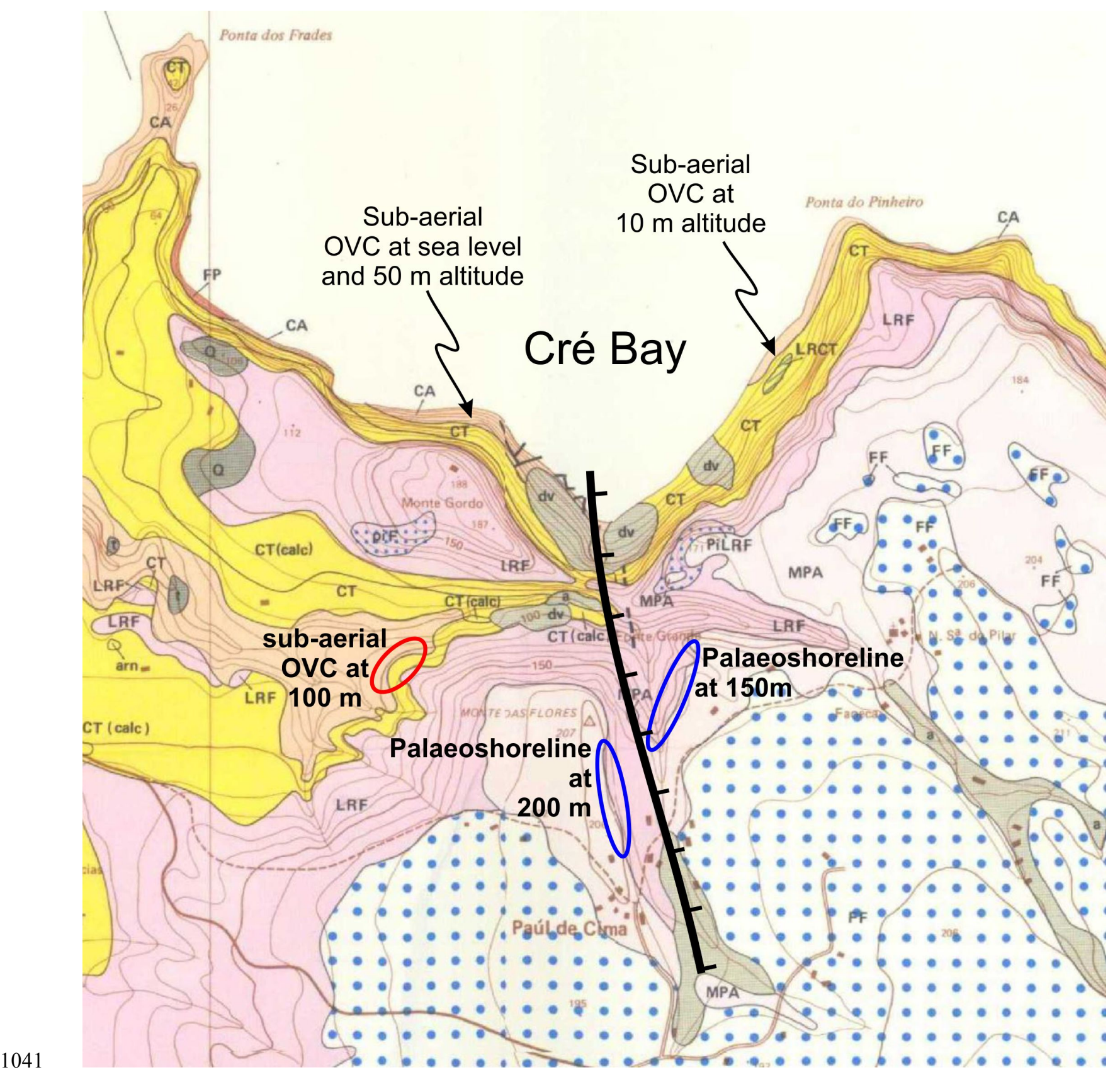

Figure S-10. Extract of the geological map by Serralheiro et al. (1987; central-north Santa Maria) to show: (1) the altitude at which ca. 3.6 Ma palaeoshorelines outcrop (blue ellipses); (2) the Cré normal fault (ticks on downthrown block) that connects to the south with the Praia Graben; (3) the ca. $50 \mathrm{~m}$ displacement on the fault; (4) that the island subsided by, at least, 100 $m$ during deposition of the YVC (with stationary sea level), because this is the difference between the altitudes of the palaeoshoreline and the underlying sub-aerial OVC (red ellipse). See legend in Fig. S-8 for colour code. 

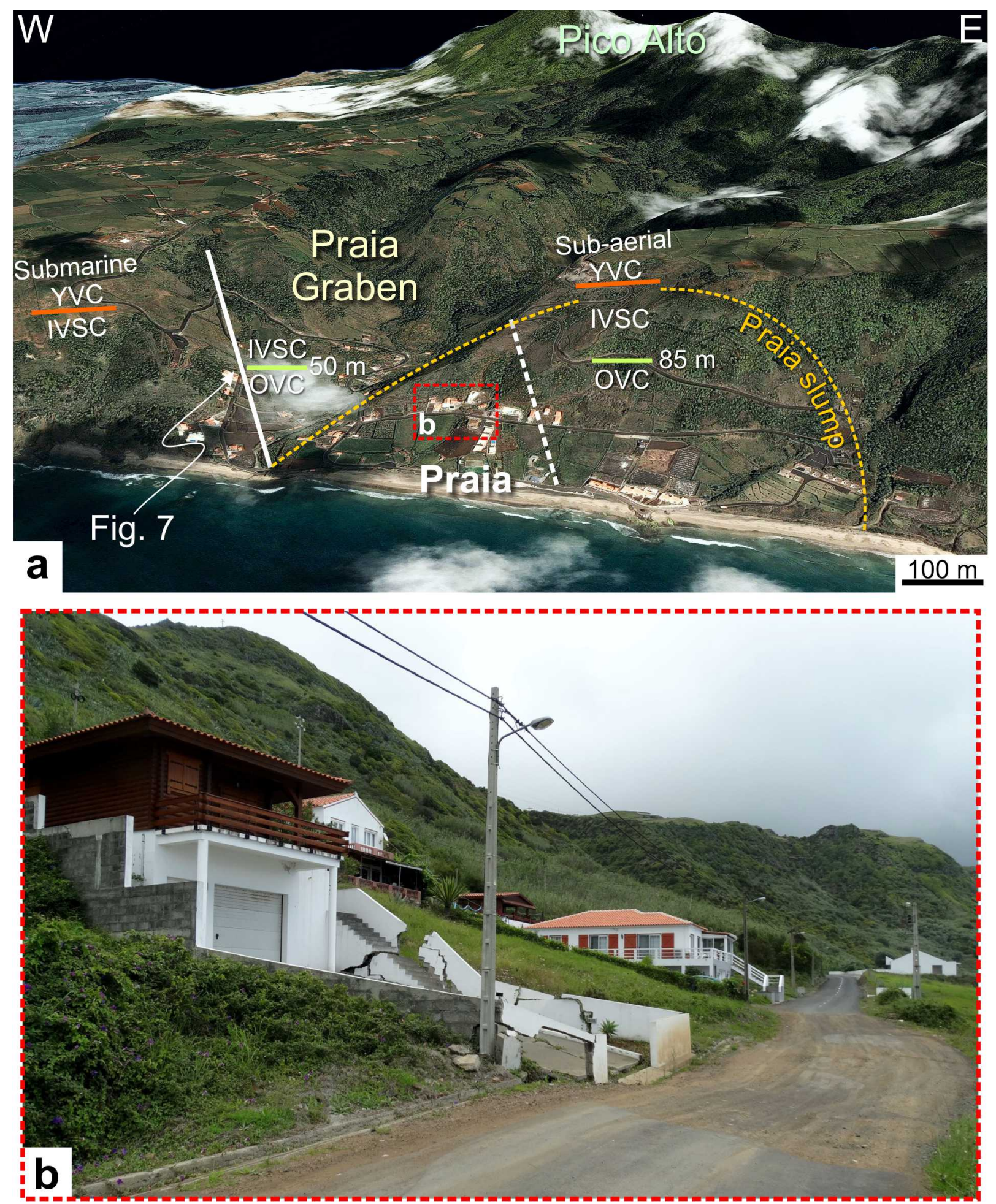

Figure S-11. (a) - 3-D Google Earth image to show: (1) the position of the passage zone between sub-aerial (east) and submarine (west) lavas of the YVC; (2) the position of the Praia Graben, defined by an observed normal fault in the west (white solid line - see details in Fig. 7) and by an inferred fault (white dashed line) in the east (from different altitude of the base of the ISC); (3) the Praia Slump, currently creeping to the south. (b) - photo of house being torn apart by the internal creeping motion of the slump, and road showing small grabens in the foreground and background. Data from SIO, NOAA, U.S. Navy, NGA, GEBCO. 